\title{
EL COMPONENTE VERBAL EN LAS ADAPTACIONES DE LA LITERATURA ÁUREA ESPAÑOLA AL CINE Y LA TELEVISIÓN: UNA PROPUESTA DE ESTUDIO
}

\author{
Rafael Malpartida TiRado \\ Universidad de Málaga \\ rmal@uma.es
}

\section{EnCAUZAMIENTO TeÓRICO Y METODOLÓGICO}

Q uien se haya adentrado, un tanto temerariamente, en el insondable piélago de la bibliografía que han generado las adaptaciones cinematográficas y televisivas de nuestra literatura áurea, tal vez habrá experimentado la sensación de que se ha agotado la posibilidad de exégesis. Este cierto efecto «paralizador» se debe, creo, a dos razones fundamentales de muy diferente tenor: la primera, de tipo cuantitativo, porque son ya muchos los libros y artículos que ha suscitado el asunto, avivado en algún caso por centenarios y conmemoraciones que han multiplicado (e incluso «forzado», diría yo) hasta la extenuación los trabajos; la segunda, de índole cualitativa, porque el objeto de estudio, con pocas excepciones, ha sido considerado de escasa calidad y (he aquí el principal problema de enfoque) a muy lejana altura de los insignes textos en los que se basan.

Ante panorama tan desolador, solo cabe el desaliento y el consecuente abandono, o bien puede emprenderse la búsqueda de algún resquicio por el que renovar esta parcela de estudio. Como prefiero esta segunda opción, hay matices decisivos que, de entrada, deberían hacernos reconsiderar esos dos factores, cuantitativo y cualitativo, aparentemente disuasorios: respecto al primero, un altísimo porcentaje de los trabajos se ha consagrado a tres autores, Cervantes, Lope y el anónimo artífice del Lazarillo, y de los dos primeros en particular al Quijote y El perro del hortelano. Es decir, tres autores y tres obras que acaparan, me atrevería a decir, más de dos tercios de lo que se ha escrito sobre la literatura española de los siglos XVI y XVII que ha migrado al cine y la televisión. En el otro escaso tercio, están principalmente representados otros textos cervantinos y lopescos, y ahí figura menguado el

Edad de Oro, XXXVII (2018), pp. 184-227, ISSN: 0212-0429 - ISSNe: 2605-3314 
resto de autores y obras de ese periodo que, nos guste ampliar a dos siglos o acotar desde Garcilaso a Calderón, hemos venido a considerar «áureo». Fíjese entonces el investigador si hay vía abierta para indagar sobre las versiones al medio audiovisual de La lozana andaluza, El Buscón, El diablo cojuelo y un largo etcétera de esos espléndidos textos en que se han fijado el cine y la televisión, y cuyas adaptaciones están perfectamente catalogadas y localizadas, con una accesibilidad, merced al cine doméstico, que ya hubieran querido los estudiosos que se contentaron con patearse filmotecas para verlas y fiarse de su memoria para escribir sobre ellas.

Pero (e ingresamos así en el segundo factor que podría resultar disuasorio) he aquí que son precisamente las adaptaciones de esos otros textos las que se han juzgado (y en muchos casos con razón) de manera más circunspecta, a lo que hemos de añadir las severas críticas que han recibido asimismo muchas de las versiones de novelas de Cervantes y de piezas teatrales de Lope, en especial las surgidas durante el franquismo.

En cuanto a los testimonios que refrendan este panorama, voy a cribar considerablemente para quedarme con los acercamientos de mayor calidad en un sintético estado de la cuestión, necesario para establecer qué se ha dicho, cómo se ha dicho y qué resta por decir. De entrada, creo que debemos soslayar, en aras de la homogeneidad, boutades que proceden de la crítica de urgencia como la de Carpentier, para quien el Quijote «es texto que rehúsa la adaptación escénica o cinematográfica. La prueba ha sido realizada cien veces, sin la menor fortuna» (1990: 192), y cercar así el panorama con estudios donde ha operado no tanto la visceralidad como la reflexión' ${ }^{1}$.

Ejemplo de ello, dado que examinan, además, un buen número de adaptaciones, son los acercamientos de conjunto de Santamarina (2002) y de España (2003), de los que parto porque los criterios que adoptan son, en cierto modo, antagónicos. Ambos concuerdan en que el saldo de la literatura áurea llevada al cine es negativo, pero Santamarina apela a menudo a la «creatividad» como factor esencial para juzgar méritos y deméritos de las diferentes películas, en tanto que España se inscribe de pleno en la llamada fidelity criticism, de modo que parte de «premisas un tanto frustrantes» y llega a lamentar, de entrada, «no sólo el escaso número de escritores adaptados, sino la completa remodelación a que han sido sometidas sus obras» (2003: 35). Así, por ejemplo, el primero destaca en El Buscón de Berriatúa, no sin antes señalar algún defecto, que se trata de «una relectura personal y creativa del texto», y se desliza «en sentido contrario a la perspectiva "señorial" y de clase del relato» de Quevedo, llegando a «enfrentarse de manera

$1 \quad$ Llega Carpentier a exclamar, como remate de su artículo: «iEscojan, pues, los cineastas de Hollywood el tema que se les antoje, pero dejen quieto a Cervantes, cuya obra se niega, por tradición, a ser llevada a la pantalla y al teatro!» (1990: 193). 
abierta a la obra original para proponer una visión personal de la misma y, en cierto modo, de la picaresca» (Santamarina 2002: 180-181), en tanto que echa en falta en el Lazarillo de Fernán Gómez y García Sánchez «una relectura más osada de la obra» (2002: 180). En cambio, España se queja una y otra vez de que poco quede de los textos literarios adaptados y celebra, por contra, que El perro del hortelano de Miró sea «respetuosa con el original» (2003: 49).

El auténtico problema de la supuesta fidelidad o infidelidad como brújula para evaluar una adaptación no es, desde luego, alguna aparente contradicción como en la que parece incurrir Santamarina cuando, en contra de sus principios, señala como demérito del Lazarillo de Fernández Ardavín que «trastoca radicalmente el sentido original del texto» (2002: 178). No es que esté aplicando un doble rasero, pues las múltiples alteraciones introducidas en ese filme no proceden de la libertad creativa, sino de la ideología impuesta desde una dictadura, y más en particular porque la película «no es solamente un vehículo de adoctrinamiento católico, sino una llamada a respetar el orden social imperante» (Cruz-Cámara y Kaplan 2002: 42)². La dificultad reside, en realidad, en que no hay manera de determinar en qué consiste esa pretendida fidelidad, de forma que el criterio está viciado ab ovo. No hay que ir muy lejos para comprobarlo: El Buscón de Berriatúa es para Santamarina, como acabamos de advertir, un ejercicio de suma creatividad que llega a subvertir el sentido del texto de Quevedo, en tanto que para España, tasador de fidelidades, «se acerca al original con bastante respeto» $(2003: 46)^{3}$. Es más, cuando se apela a la cantinela de la fidelidad o el respeto (que, no lo olvidemos, son términos de filiación moralizante), ¿es en sentido unívoco, es decir, un filme es mejor por ser más «fiel» al texto de partida? Para la llamada fidelity criticism, desde luego que sí, pero prueba de la poca consistencia de esa ofuscada detección de «mentiras y alteraciones», como definía Wolf (2001: 21) la tendencia, es que El Buscón es juzgada negativamente por España aun siendo, en su opinión, bastante «fiel» a su fuente literaria.

Es este un escollo metodológico que no afecta solo, naturalmente, al estudio de las adaptaciones del Siglo de Oro, pero que se agrava en mayor medida cuando los textos literarios mudados al cine o la televisión gozan de gran prestigio y

2 Para que no quepa duda de que estamos ante un caso en que no se obra con libertad, véase el revelador cotejo de Acosta Romero entre las principales decisiones tomadas en el filme y la versión depurada del Lazarillo de 1573 (1998: 18-19). Habría que evitar, así, que en un estudio exclusivamente intrínseco se llegue a dictaminar, por soslayar el contexto de producción, que la película aventaja al texto literario (Shu-Ying Chang 2002: 519-522). Un estudio de ese tipo que incida en el lenguaje cinematográfico debe sentarse en sólidas premisas teóricas y metodológicas, como propuso Tejada Medina (1997) para un capítulo de la serie televisiva El Quijote de Gutiérrez Aragón.

3 Nótese también, para el caso de El perro del hortelano de Pilar Miró, que dos artículos logrados como los de Alonso Veloso (2001) y Díez Ménguez (2002) difieren precisamente a la hora de tasar el grado de fidelidad que presenta el filme respecto al texto de Lope. 
se juzga que su calidad parece inalcanzable para los medios que vuelven a recrearlos, como si hubieran de entrar en competencia con ellos. Así, una cuestión emparentada con esta de la fidelidad es la de la «potencialidad» y el «desaprovechamiento». Un trabajo que erige esas dos ideas como hilo conductor es el de Quesada, para quien, respecto al período del Siglo de Oro:

[e]sta prodigiosa época, extraordinariamente fecunda en las Letras y en las Artes plásticas, que modela el carácter español en el intervalo existente entre el cénit de la grandeza y los primeros indicios de la decadencia, donde aparecen las primeras grandes novelas y obras teatrales que mezclan el realismo con la crítica social y moralista, esta época de eclosión cósmica del genio español, aunque ha sido aprovechada por el cine no lo ha sido suficientemente ni en cantidad, ni en calidad, ni en profundidad (1986: 27).

Tras semejante proclama, por no decir soflama, no es de extrañar que, por ejemplo, considere una película como El Buscón «falta del vigor y del desgarro auténticos del original» (1986: 42), o que opine que Ramón Fernández, en El diablo cojuelo fílmico, «desaprovechó totalmente las posibilidades que le brindaba el texto» (1986: 42). Esto significa que la gran calidad de una obra literaria debe trasvasarse, casi por decreto y no sé si a través de algún misterioso canal, a la obra cinematográfica, cuando la práctica de las adaptaciones demuestra más bien lo contrario: es preferible elegir textos de escasa calidad o muy poco conocidos, como ilustró el cineasta que me parece más inteligente a la hora de tomar de la literatura lo que mejor servía a sus intereses: Alfred Hitchcock (Malpartida Tirado 2018: 42-43).

En línea contraria, aunque aún en el área de irradiación de la fidelity criticism, está la idea de que esos textos canónicos son inaprehensibles para el cine. Y al frente de ellos, claro, figura el Quijote, como ya apreciamos en la airada protesta de Carpentier. En el mismo sentido se manifestaba Blas Matamoro cuando titulaba elocuentemente su artículo sobre las versiones fílmicas de la obra magna de nuestra literatura como «En ningún lugar de la Mancha» (2003). Muy llamativa es, además, la contundencia con la que a menudo se despacha el asunto, y no porque una u otra versión sea juzgada de forma malhumorada, sino porque llega a afirmarse, respecto a todas ellas en su conjunto, que «don Quijote sigue esperando, con su espada desenvainada en el escenario de la proyección, que el cine de luces y sombras le acepte como una figura de ficción y no como un enemigo que destroza la pantalla en cada una de sus adaptaciones» (Praga Terente 2016: 171) .

4 Posibles antídotos para todas estas tendencias que giran en torno a los conceptos de «fidelidad» o de «superioridad», son, si se encauzan con precaución, las últimas propuestas relacionadas con la mitocrítica, que no por casualidad han empezado a consolidar términos como «más allá de la adaptación»o «reescritura» desde el propio título de sus trabajos (Pardo García 2011 y 2013) y 
La nómina de detractores enfurecidos con cualquier adaptación del Quijote es tan larga que requeriría un estado de la cuestión monográfico y no este breve pórtico que ofrezco aquí. Es así, sin duda, la célebre novela de Cervantes el texto que más ha sido sometido a la prueba de la fidelidad, y con la salvedad de los dos acercamientos de Gutiérrez Aragón ${ }^{5}$, que, aunque no de manera unánime, sí han granjeado sus partidarios (por ejemplo, Sánchez Noriega 2005; Hernández 2005; Usero Cañestro 2005; Buezo Canalejo 2008), el veredicto ha sido muy negativo. Sucede además que el Quijote, en sus variadísimos trasvases al cine y la televisión, ha caído en la mayor trampa de las que ha urdido la fidelity criticism:

La crítica de la adaptación provee una serie de «dilemas» y de «círculos viciosos». Una película «fiel» es vista como poco creativa, pero una película «no fiel» es una traición vergonzosa al original. [...] Parece como si el adaptador nunca pudiera ganar (Stam 2014: 31).

Ni que decir tiene que esos vaivenes en los criterios metodológicos de muy diferentes investigadores han zarandeado con rigor a las versiones fílmicas del texto cervantino, pero es que pueden encontrarse incluso en un mismo trabajo, como el bien documentado y valiente en sus juicios de Emilio de la Rosa sobre las «adaptaciones animadas» del Quijote, pero cuya siguiente afirmación parece escrita para ilustrar la paradoja que exponía Stam:

Si la versión australiana peca de vacía y de exceso de licencias con respecto al original, la serie dirigida por Cruz Delgado y titulada Don Quijote de la Mancha (1978), peca de lo contrario, de un seguimiento al pie de la letra del texto de Cervantes, olvidando un mínimo de imaginación (1998: 112) .

han procurado ofrecer una extensa relación de títulos que no sean adaptaciones, sino que retomen el texto «solo por alguno de sus flancos» (Bonilla Cerezo 2015: 48-51); o las que han considerado el Siglo de Oro de forma global en su relación con el cine y la televisión, como una reciente tesis doctoral que acaba de convertirse en libro (López López 2017). Por otra parte, la sugestión de lo que podría denominarse adaptación compuesta o mixta, es decir, la que se basa no solo en un texto literario, sino que también tiene en cuenta otra adaptación previa, como apunta Lara para el caso del Quijote de Kozintsev, que mira al de Pabst (1998: 82), podría contribuir a que vayamos superando los lugares comunes sobre la «fidelidad».

5 Y digo solo dos porque la que podría considerarse otra mirada del realizador al texto cervantino, La noche más hermosa, poco debe en realidad a «El Curioso Impertinente» como texto literario (Malpartida Tirado 2018: 663-666).

6 A esto habría que sumar un matiz algo desconcertante que añade un poco más adelante, y que permite apuntalar la idea de que nadie sabe en realidad qué se entiende por «fidelidad»: «Muchas veces se dice que esta versión [la de Cruz Delgado] es la más fiel al original, pero no es cierto, ya que esa supuesta fidelidad se refiere a la servidumbre que la serie tiene con respecto al texto, olvidando dar su propia visión de la novela y, desde luego, sin profundizar en absoluto en lo que 
Por fortuna, hay investigadores que, con buen tino, han intentado desechar este principio metodológico errado, pero se les ha deslizado, diríase como prueba de su resistencia, en alguna ocasión (Gómez Mesa 1978; Lara 1998; Utrera 2001). Creo que quienes con mayor vigor han reclamado un viraje (y sigo ciñéndome al caso paradigmático del Quijote) y lo han aplicado coherentemente a sus pesquisas, son Hernández Ruiz (1998) y Herranz (2005)7. El primero de ellos inicia su trabajo con este decidido aldabonazo:

La mayor parte de los estudios que relacionan el cine con la obra cervantina lo hacen desde una perspectiva muy ilustrativa, ciñendo su disertación en torno a la mayor o menor fidelidad de las adaptaciones fílmicas respecto al original literario. No voy a sumarme a este tipo de operaciones, que tienen todavía muchos recovecos que auscultar, aunque casi siempre con un discurso bastante reiterativo y adaptado a plantillas comparativas no especialmente sofisticadas (1998: 139).

Y Herranz, en su espléndido monográfico, realiza esta declaración de intenciones:

el presente trabajo no se centra en el potencial cinematográfico del Quijote, sino en sus adaptaciones, en la medida en que las narraciones cinematográficas condensan, trucan, magnifican, desvirtúan, burlan o parodian (parodia de la parodia, en este caso) la novela o el personaje. Y ante todo cabe preguntarse, atendiendo, por ejemplo, a las radicales diferencias de ejecución que presentan tres adaptaciones coincidentes en su propósito de fidelidad a la obra (Rafael Gil, Cruz Delgado y Manuel Gutiérrez Aragón [serie]): ¿qué es ser fiel al Quijote? Un recorrido por las diversas transposiciones de la novela a la pantalla no contribuirá necesariamente a responder a esta cuestión, sino (y éste es nuestro objetivo) a delimitar algunas de las múltiples visiones interpretativas de las que la obra literaria ha sido objeto por parte del medio audiovisual (2005: 13).

Es, sin embargo, aún más fecunda para lo que voy a proponer, esta otra afirmación del autor:

Cervantes no escribe pero refleja en sus personajes o en sus aventuras. Fidelidad en este caso es la mayor traición a unas ideas que no necesitan seguir el texto para poder plasmarse» (1998: 112). $\mathrm{Al}$ margen de que parece olvidarse que es al público infantil al que principalmente va dirigida una serie de animación como esa, creo que la idea hacia la que se desliza la objeción es la del «espíritu» del texto, forma relajada de la exigencia de la fidelidad sobre la que ya intenté alertar en otro lugar (Malpartida Tirado 2018: 26-27).

7 Conviene añadir, en la estela de este último, pero asumiendo además la riquísima introducción teórica de Zecchi con que se abre el libro colectivo en el que participa y apoyándose en el combativo Stam (mimbres metodológicos con los que creo que todo estudio comparativo entre literatura y cine puede encauzarse con bastantes garantías), el artículo de Briones Manzano (2012). 
la bibliografía existente sobre el Quijote y el cine - con la honrosa excepción de la obra colectiva Cervantes en imágenes, cuya diversidad de discursos permite que trasluzca una visión objetiva y, finalmente, unitaria de cómo el cine ha abordado la literatura cervantina - se ve limitada a explorar lugares comunes que provienen de la ausencia de monografías: a partir de las limitaciones de tiempo y extensión inherentes a los artículos suele aflorar el ceñimiento a la abstracción sintética - se habla, en términos generales, de obras fieles o infieles, de films que desmerecen o hacen justicia al personaje, que logran o no reflejar su espíritu, que están cerca o lejos de la grandeza moral de don Quijote - y, más allá de los episodios y personajes por todos conocidos, no suelen explorar los vínculos con la obra literaria, sino con el vago recuerdo que queda de ésta (2005: 11-12).

Si estas dos palabras clave, «abstracción» y «vago recuerdo», en proporción distinta, han determinado una buena parte de los trabajos sobre el Quijote y la literatura española áurea en el cine, mirar hacia el componente verbal de las adaptaciones creo que solventa en buena medida ambos escollos, porque obliga a cercar el objeto de estudio y, de este modo, el cotejo entre ambos cauces artísticos resulta, para empezar, más directo y concreto.

Aunque apenas se ha abordado este aspecto que quiero reinvindicar, algo mayor ha sido la atención de la crítica al ámbito verbal en el caso de las adaptaciones teatrales. Contamos, por ejemplo, con aportaciones valiosas incluso desde un punto teórico y tipológico (Pérez Bowie 2001; Sánchez Noriega 2011), una atinada advertencia «acerca del peligro de subestimar el diálogo en el marco de los estudios en este campo» (Trecca 2015: 166-167), y aplicaciones prácticas no con excesivo detenimiento en lo puramente lingüístico pero que constituyen una piedra de toque para que empecemos a estudiar estas películas por dicha vía.

La razón fundamental de que sí se haya atendido en ocasiones al componente verbal es la problemática específica del verso y que dos filmes se han beneficiado de un evidente auge, a partir de finales de los noventa, en el campo de estudio de las relaciones entre la literatura y el cine, El perro del hortelano y La dama boba. En particular, la película de Pilar Miró ha suscitado ingente bibliografía, con trabajos de calidad como los de Cortés Ibáñez (2000) y Alonso Veloso (2001), que han incidido en lo verbal, o los de Jaime (2000: 210-231), Pilar Nieva de la Paz (2001), Escalonilla López (2002), Díez Ménguez (2002), Fernández y Martínez-Carazo (2006) y Thiem (2009), más de pasada por ser los suyos estudios centrados en aspectos estructurales, técnicos y del lenguaje de las imágenes, pero estableciendo bien su relación con los diálogos. Algunos de ellos, eso sí, aún se han movido en los límites de la fidelity criticism.

Es esta de la dramaturgia, además, la parcela más activa en las investigaciones actuales sobre la literatura áurea y el cine, con artículos excelentes como los de Trecca (2011) y Noble Wood (2015) sobre La dama boba, tesis doctorales en curso con prometedores adelantos en forma de artículo (Carmona 2015; Carmona 
y Boadas 2016), o el reciente número del Anuario Lope de Vega sobre «La escena y la pantalla. Lope hoy», al frente del cual se llama la atención sobre lo erróneo de «ideas que aún se utilizan para valorar cualitativamente las relecturas de obras clásicas, por ejemplo las vinculadas con nociones como "fidelidad" o "lealtad"» (Carmona, García Mascarell y Gilabert 2018: 3), en lo que insiste uno de los trabajos incluidos en ese monográfico, la sugerente apuesta de Wheeler (2018: 271 y 277), de manera que se puede otear en el horizonte un más que necesario replanteamiento metodológico como el que propongo aquí.

\section{CAlas en las adaptaciones de la narRativa ÁURea}

Un ejemplo de adaptación generalmente vituperada (hecha excepción, como hemos comprobado, de Santamarina) es El Buscón (1975) de Luciano Berriatúa, a quien Augusto M. Torres incluyó entre los Directores españoles malditos, resaltando el fracaso comercial del largometraje (2004: 60-61); de hecho, se le conoce y cita mucho más como especialista en Murnau y el expresionismo alemán, y en calidad de restaurador de películas, que como realizador. Por otra parte, si lo deslavazado o episódico del relato es una de las principales objeciones que ha recibido la película, nótese, sin embargo, que ya ha resaltado la crítica, en la discusión sobre su adscripción a la picaresca, la peculiar estructura del propio texto literario, como sintetiza bien, por ejemplo, Güntert (2006: 149-150). Y hay también quien le da la vuelta a esa cierta desorganización del texto audiovisual y opina que «El Buscón está narrado de una manera muy libre y audaz y, en muchos momentos del filme, da la sensación de ser un carrusel de imágenes desbordantes en el que debemos prestar igual atención a los personajes que están en primer término diciendo sus frases como a lo que está sucediendo en el fondo del plano» (Miguel Borrás y Úbeda-Portugués 2010: 16), además de que el propio Berriatúa declaraba en una entrevista a los citados investigadores que «no tenía una estructura narrativa. Eran cuadros separados casi a hachazos» (2010: 24).

En todo caso, no es de extrañar el generalizado desafecto hacia el largometraje, porque no es un trabajo muy logrado en sí mismo, pero, en relación al texto en que se basa y atendiendo a cómo adapta el componente lingüístico, conviene advertir lo siguiente: no se contenta con trasladar linealmente el relato de Quevedo, sino que arranca incluso con un doble motivo y altera el orden de los pasajes que emplea, comenzando por el capítulo VII y la carta del tío de Pablos, y multiplicando y dinamizando las voces y las modalizaciones (de estilo directo a indirecto y viceversa, del «tú» epistolar al «yo» del narrador); acude a la voz over pero ni abusa de ella ni parece pretender el «reconocimiento» del texto por parte del espectador (elude, por ejemplo, la célebre y logradísima descripción del licenciado 
Cabra); retoma a menudo términos y frases de la obra pero los «envuelve» en cierto remedo de lenguaje arcaizante no mal encaminado; y no considera que el receptor, por ser espectador de cine y no lector de un texto literario, requiera excesivas modernizaciones ni glosas explicativas para entender a los personajes.

En esto último habríamos de detenernos, pues es El Buscón de Quevedo un festín dilógico y podría pensarse que Berriatúa confía demasiado en el paladar de los espectadores, no por el lugar común de que quien está ante una película pierde o aminora sus capacidades intelectivas, sino porque debe cazar las malicias, a menudo harto complejas, al vuelo y no con el reposo que permite el libro en las manos. Por citar dos ejemplos contrarios de sesgo escatológico, el «dicen que daba paz cada noche a un cabrón en el ojo que no tiene niña», trasladado del texto quevediano mediante voz over epistolar, podría representar alguna dificultad, y, de hecho, se aprecia en la tabla comparativa del siguiente apartado que dedico al teatro que en la versión televisiva de El perro del hortelano se percibe como problemática «dar la paz» en su acepción de 'besar'; en cambio, en otras ocasiones opta por apoyarse en algún elemento visual que «fije» el sentido, lo que le permite incluso ser menos explícito verbalmente que el texto, pues la imagen ya cumple la función aclaratoria:

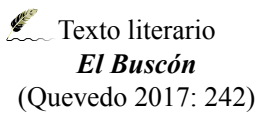

Llamábanle el Jayán. Decía que estaba preso por cosas de aire, y así, sospechaba yo si era por algunas fuelles, chirimías o abanicos, y decíale si era por algo desto. Respondía que no, que eran cosas de atrás. Yo pensé que pecados viejos quería decir. Y averigüé que por puto.

\section{Texto fílmico \\ El Buscón}

(L. Berriatúa, 1975)

PABlos: ¿Quién es este?

Preso (en off): Preso es.

PABlos: ¿Por gerifalte?

Preso (en off): No, sino por cosas del aire.

PABlos: ¿Cómo es eso? ¿Robaste fuelles o abanicos?

JAYÁN: No, por pecados de atrás.

PABLos: ¿De tiempo atrás?

JAYÁN: No, de atrás [y se cimbrea para que se fije en el trasero, con estruendo de risas entre los otros presos].

Es notable el modo en que se logra imprimir dinamismo mediante la conversión en diálogo directo, y «gerifalte», voz de la germanía, sustituye bien la mención a los «fuelles, chirimías y abanicos» porque se renuncia a la acepción de 'soplones' simplificándola con la de 'ladrones', pero a cambio se confía en el gesto del personaje y se deja más velado lo que la voz narrativa aclara cuando se alude a lo que averiguó finalmente. 
Por otra parte, se ha acusado precipitadamente a Berriatúa de indolencia a partir de una declaración de él mismo: «considero impenetrable el texto original» (Gómez Mesa 1978: 219); pero ningún indicio hay de que se tomara con liviandad la incorporación del texto quevediano, dado que no se contenta con acudir a la obra matriz y que da título al filme, sino que llega a emplear otros textos del autor. Resulta muy llamativo, y bien alejado de la indolencia, que el realizador y guionista llegue a poner en boca del padre de Pablos un fragmento de uno de sus Sueños y discursos, concretamente el del Infierno:

Texto literario 1

El Buscón

(Quevedo 2017: 101)

-Quien no hurta en el mundo, no vive. ¿Por qué piensas que los alguaciles y jueces nos aborrecen tanto? Unas veces nos destierran, otras nos azotan y otras nos cuelgan, aunque nunca haya llegado el día de nuestro santo. No lo puedo decir sin lágrimas - lloraba como un niño el buen viejo, acordándose de las veces que le habían bataneado las costillas - ; porque no querrían que, adonde están, hubiese otros ladrones sino ellos y sus ministros.

\section{- Texto literario 2}

Sueño del infierno

(Quevedo 1993: 227)

Éstos son los boticarios, que tienen el infierno lleno de bote en bote, gente que como otros buscan ayudas para salvarse, éstos las tienen para condenarse. Éstos son los verdaderos alquimistas, que no Demócrito Abderita en el Arte Sacra, ni Avicena, Geber, ni Raymond Lulio, porque ellos escribieron cómo de los metales se podía hacer oro, y no lo hicieron ellos; y si lo hicieron, nadie lo ha sabido hacer después acá: pero estos tales boticarios, del agua turbia (que no clara) hacen oro, y de los palos; oro hacen de las moscas, del estiércol; oro hacen de las arañas y de los alacranes y sapos; y oro hacen del papel pues venden hasta el papel en que dan el ungüento.

\section{Texto fílmico El Buscón}

(L. Berriatúa, 1975)

Padre de Pablos: Quien no hurta en el mundo, no vive. ¿Por qué piensas que los alguaciles y jueces nos aborrecen tanto? No lo puedo decir sin lágrimas [se levanta la ropa y vemos en plano de detalle cicatrices en sus costillas]. Porque no querrían que hubiese otros ladrones más que ellos y sus ministros.

MAdRe de PABlos: ¿Eso quieres para tus hijos? ¿Un cuerpo que de tan molido no se tenga en pie? Brujos han de ser, o alquimistas.

Padre de Pablos: ¿Alquimistas? Comerciantes, boticarios: esos son los verdaderos alquimistas y no Demócrito ni Raimundo Llull. Ellos escribieron cómo de los metales se podía hacer oro, y no lo hicieron ellos; y si lo hicieron, nadie lo ha sabido hacer después acá. Pero los comerciantes, del agua turbia hacen oro, y de los palos; oro hacen de las moscas, del estiércol; y oro hacen del papel, pues venden hasta el papel en que dan el ungüento.

Es muy lograda la fusión del texto de los Sueños con el parlamento de El Buscón gracias a que se inserta una réplica de la madre (de cosecha propia y con estratégica mención a los alquimistas para enfilar oficios, como gustaba a Quevedo) que funciona como eficaz bisagra entre turnos. Así, el procedimiento, emparentado con la «imitación compuesta», que «ofrecía el riesgo previsto por Séneca: $[\ldots]$ 
que resultara un zurcido inhábil» (Lázaro Carreter 1979: 96), sortea el peligro de que se le noten las costuras. Por otra parte, la referencia importada de la segunda fuente se debe a que Berriatúa es consumado especialista en ocultismo y, de hecho, su primer cortometraje, de 1971, se llamó El alquimista.

Mucho más fácil de detectar es la recurrencia a dos célebres poemas satíricos de Quevedo, la letrilla «Poderoso caballero es don dinero», de la que se cantan varias estrofas hasta en tres ocasiones, y el soneto «Érase un hombre a una nariz pegado», que en un divertido momento empieza a recitar Ana Belén mientras toca la nariz de Pablos. La primera, desde luego, emparenta mejor con la trama (y por eso abre y cierra el filme), dado que la segunda constituye un simple guiño al autor.

No quiero decir con estos apuntes que la película sea mejor cinematográficamente de lo que se ha señalado (puede que estos sean solo aciertos parciales), sino que hay vías para explorar soluciones creativas y hábiles desde el punto de vista lingüístico, y puede deparar sorpresas como la incorporación de un parlamento de los Sueños en un filme del que la mayoría de investigadores huíamos simplemente por su mala reputación.

Si en busca de otras posibilidades de adaptación de El Buscón, enriquecemos el estudio acudiendo a la serie televisiva El pícaro (1974), notaremos que Fernán Gómez y sus guionistas obran de manera similar en lo que atañe a la lengua de los textos que incorpora ${ }^{8}$, y de igual modo parece confiarse en la capacidad del espectador si analizamos sus operaciones de modernización y sus oportunas adiciones. Resulta muy interesante para nuestro propósito (y me refiero ahora al conjunto de la serie) que les baste a los guionistas lo que podríamos denominar un cierto «aroma arcaizante»: si son rigurosísimos, por ejemplo, con «la fantasma» en femenino o con «por cierto» como 'ciertamente', en el excelente capítulo del doctor Sagredo y doña Mergelina, extraído del Marcos de Obregón de Vicente Espinel, usan «ventano» (esto es, 'ventana pequeña', la cual queda fuera de campo, así que no es decisión motivada por lo que muestran las imágenes) aunque el texto indica «ventana» (Espinel 1972: 101), y el término, si nos ayudamos del NTLLE, no aparece en los diccionarios hasta el siglo XIX ni el CORDE lo consigna para nuestra literatura del Siglo de Oro. No creo, sin embargo, que esto disuene para el espectador, pues solo a través del estudio, y no en la recepción in fieri, pueden detectarse estas minucias léxicas, y más interesante es el modo en que se transforma

$8 \quad$ El propio Berriatúa emparenta sus adaptaciones, que se rodaron simultáneamente (Miguel Borrás y Úbeda-Portugués 2010: 23-24). Disponemos ahora, además, de una reciente monografía (España Arjona 2017) donde son identificados y ubicados con minuciosidad los textos que $E l$ pícaro incorpora, y en lo que respecta a la novela de Quevedo, hay que atender a los capítulos 2 , 5, 10 (que contiene el episodio de los reos al que antes aludimos) y 11 de la serie. 
y recompone la sintaxis, ámbito este del que más provecho podría extraerse para la investigación sobre el componente verbal en la estupenda serie. Es notable, además, el sentido del humor (como el que derrocha el magnífico texto de Espinel) que se activa con esta adición, a propósito del «desapacible» que le arrojaron al joven amigo de Marcos desde el citado ventano: «ipara qué quieres que mire, hijo mío, si con oler nos basta?». Se trata de una ingeniosa conversión en diálogo del escueto «entró quejándose» (Espinel 1972: 101) al que alude la voz narrativa.

En cuanto al Lazarillo de Tormes, el de Fernán Gómez y García Sánchez (Lázaro de Tormes, 2001) es, en puridad, la adaptación de una adaptación, el monólogo teatral que llevó a las tablas Rafael Álvarez el Brujo (Brasó 2002: 255-256), de modo que resulta más difícil tasarlo respecto a su vertiente lingüística (habríamos de tener acceso, para empezar, a ese otro texto «puente»). Pero si atendemos al que César Fernández Ardavín realizó en 1959 en la línea del impuesto nacional-catolicismo y según las pautas del «mercado vigilado» de esa década que tan bien han explicado Pérez Bowie y González García (2010), se puede indagar con garantías porque el diálogo que establece con el texto resulta (y perdónese el intento de juego de palabras) francamente diáfano. Eso implica que hay en el filme una evidente intención, como han señalado dichos estudiosos, de «corregir los defectos morales del texto original» (2010: 133), y no hay que olvidar que, más en particular, se inscribe en la dinámica de las «películas con niño» (Cruz-Cámara y Kaplan 2002: 41; España Arjona 2018: 20)9 . De este modo, las protestas de su productor por «su clasificación para mayores de dieciséis años, pensando que podría perder un público importante, precisamente aquel que tenía la obra literaria como lectura obligatoria en los centros de enseñanza» (Pérez Bowie y González García 2010: 132), nos sitúan en la órbita de qué planes había para una adaptación de este sesgo ${ }^{10}$. Así, la sustitución sinonímica, incluso para términos que no deberían

$9 \quad$ Por ejemplo, frente a la aséptica despedida de la madre en el texto literario, tan idónea para lo que está contando (1994: 22), la lacrimógena secuencia del filme de Ardavín hay que tasarla en relación a ese popular «cine con niño», de tendencia sentimentaloide, no al propio Lazarillo, porque la novela no constituye el referente, sino otras películas de esa década como Marcelino, pan y vino (1954), la lograda Mi tío Jacinto (1956) o Un ángel pasó por Brooklyn (1957), todas ellas, por cierto, dirigidas por Ladislao Vajda y con Pablito Calvo como estrella infantil. No es que sea, por tanto, la película de Ardavín «infiel» al texto literario, sino que ni siquiera lo tiene en cuenta, porque el impulso creativo está en otro lugar (en este caso, en el propio cine), lo que vuelve a evidenciar que la fidelity criticism ha errado en sus métodos.

10 La película, claro, obtuvo incluso la categoría de «Interés Nacional», dado que además había sido premiada en el Festival de Berlín, probablemente por razones de tipo técnico que, por otra parte, la crítica ha elogiado de manera prácticamente unánime. Y que el criterio de la supuesta «fidelidad» al texto literario es del todo improductivo queda de nuevo de manifiesto porque a Gómez Mesa, por ejemplo, le parece que «la película no defrauda al lector que se deleitó con la novela» (1978: 35), en tanto que ya tempranamente hay quienes se echaron las manos a la cabeza 
suponer dificultad alguna, máxime cuando la imagen ofrece potentes asideros de sentido, es la tónica: por ejemplo, en el célebre episodio de la calabazada que propina el ciego al niño, el arcaísmo verbal de «llega el oído a este toro» (Anónimo 1994: 23) se anula con un «acerca», y a continuación «necio» se convierte en «imbécil».

Esto no quiere decir que no merezca la pena ahondar en la pericia que se exhibe ocasionalmente a la hora de transformar lingüísticamente el texto de partida, por arteras que fueran las intenciones. Por ejemplo, el episodio de Zaide, «síntoma de esa España peninsular donde las actividades y pensamientos esclavistas proliferaron, pero de la que - acaso como una manera de mantenerla en el olvido- poco se ha estudiado» (Carrera 2001: 14) ${ }^{11}$, y que podría, por tanto, suscitar nuestras suspicacias como analistas, es muy hábilmente trasladado en el filme porque la sentencia se pone en boca no del Lazarillo que, «aunque bien mochacho» (y nótese que el inciso es una prevención), ya tenía juicio para pensar «iCuántos debe de haber en el mundo que huyen de otros porque no se veen a sí mesmos!» (Anónimo 1994: 18), sino en la del adulto ciego. Se trata de una reubicación y selección del asunto, del que se muestra solo esa parte, y como el diálogo imprime dinamismo, se espera a que el protagonista encuentre al ciego para insertarlo en forma conversacional. Pero, sobre todo, aporta verosimilitud, dado que en el propio texto literario se ha advertido la brecha entre el recuerdo infantil y la voz adulta que lo asume (Fra Molinero 1993: 24).

Sin embargo, no parece que este sea el propósito fundamental de la tibia adaptación lingüística del filme, ya que al prescindirse de la perspectiva adulta del protagonista (atalaya narrativa que se erige en el texto literario para modular perfectamente lo que se dice y piensa, siempre desde esa marcada y calculada distancia), son abundantes los términos puestos en boca del pequeño Marco Paoletti

cuando obtuvo tan prestigioso galardón internacional, y se le reprochó a la película que «no es que esté equivocada en parte o en sus elementos periféricos o en algún rasgo aislado, es que la versión cinematográfica que se nos ofrece está absolutamente equivocada, sin que en ningún solo momento acierte a dar con el camino justo ni con el tono oportuno que nos aproximen a lo que debería ser una traslación en imágenes de lo que a través de las palabras nos ha conmovido y nos ha interesado tan hondamente. No se trata de una desviación; se trata de una traición» (González Egido 1960: 24).

11 Nótese, sin embargo, que ya hay disenso a la hora de tasar las intenciones del anónimo autor del Lazarillo literario cuando introduce a Zaide, pues se ha vinculado a «una imagen positiva, liberal, antirracista, que [...] se relaciona con el carácter cuestionador de la novela» (Carrera 2001: 19), pero también se ha concluido que «tanto éxito tiene Lázaro en su marginalización de Zaide que los críticos lo han ignorado o lo han tratado como el mismo Lázaro "quisiera"» (Fra Molinero 1993: 27). Claro que estas dos posturas no son del todo divergentes, pues el término «ironía» con que tantas veces hemos creído salir venturosos al estudiar el texto, poniendo así en cuestión al propio protagonista-narrador, relativiza asimismo cualquier juicio (probablemente anacrónico, además) que podamos establecer sobre las palabras de Lázaro: ¿es racista o refleja el racismo; emplea el autor el racismo para denunciar una nueva iniquidad? 
(doblado, para más inri) que resultan inapropiados para tan corta edad: así, «lacería», término clave de la obra, resulta ridículo cuando lo introduce el chiquillo para vincularlo con su nombre. Contrasta esa forzada recurrencia a vocablos de la fuente literaria con pasajes donde sí parece tenerse en cuenta la candidez con que se ha preferido caracterizar a este Lazarillo fílmico, de manera que se generan engendros como este:

Texto literario Lazarillo de Tormes

(Anónimo 1994: 54)

Pensé muchas veces irme de aquel mezquino amo; mas por dos cosas lo dejaba: la primera, por no me atrever a mis piernas, por temer de la flaqueza que de pura hambre me venía; y la otra, consideraba y decía: «Yo he tenido dos amos: el primero traíame muerto de hambre, y, dejándole, topé con estotro, que me tiene ya con ella en la sepultura; pues si déste desisto y doy en otro mas bajo, ¿que será sino fenescer?».
8 Texto fílmico

El Lazarillo de Tormes

(César Fernández Ardavin, 1959)

Santa Rita, desde que mi amo arregló el arcaz, estoy pensando dejarle, pero no me atrevo por dos razones: la una, por miedo a tiempos aún peores; la otra, porque si mi primer amo me quería hacer morir de hambre, y este me lleva hacia la sepultura, si caigo en manos de otro aún peor, no me queda más que morime. ¿Qué haría? Es un lío...

Que se le plante semejante «interlocutora» (Santa Rita, ante cuya representación habla) es, sin duda, consecuente con el entremado ideológico que se edifica, además de que permite de nuevo una suerte de diálogo implícito (que confía, claro, en que una santa «responda», frente a la desconsolada interrogación retórica del Lazarillo de papel), pero mantener «arcaz» y, en cambio, sustituir «fenescer» por «morir» no parece muy coherente, de igual modo que, en el plano gramatical, «la primera»y «la segunda» razones del texto literario ya funcionaban bien como para mudarlas en «la una» y «la otra». El «lío» final es remate digno de las operaciones poco cuidadosas que se efectuaron, y que, insisto, habría que tasar mirando más hacia las películas «con niño» (en este caso, muy en particular, hacia Marcelino, pan y vino) que buscando «fidelidades» respecto al texto de partida.

De la exclusiva (y, por tanto, chata) perspectiva infantil elegida para la película, deriva otro problema que afecta a la armonización de los parlamentos: por ejemplo, el dechado de malicia prospectiva que representa la alusión a los cuernos (Anónimo 1994: 37, n. 109) resulta del todo punto estéril y postizo en el filme cuando lanza la predicción el ciego, pues este edulcorado Lazarillo (que, desde luego, no tiene ni idea de a qué se refiere su interlocutor) nunca será Lázaro, frente a la decisión axial del filme que rodaron Fernán Gómez y García Sánchez, y de la que tanto rédito obtuvieron. 
Y llama la atención, al tratarse de una mixtificación, que la cita inicial de la película, mediante rótulo, sea una frase de cosecha propia que se endosa a san Agustín: «El hambre es mala consejera, pero son peores la mentira, la superstición y la ignorancia. Descubridlas, y os acercaréis al Dios verdadero». Y no lo digo porque no sea efectiva (ya que es la inequívoca declaración de intenciones del filme), sino porque buen surtidor de sentencias morales tenían en esa línea, empezando por el propio hipponensis, señor arrepentido como el niño de la película, según notamos en sus Confesiones, y eso es justo lo que descubrimos que le sucede a este nuevo Lazarillo cuyo principal problema no es el hambre o la barbarie que lo rodea, sino que se ha apartado de los preceptos católicos (ese es «el caso») y debe dar cuenta de su descarrío.

Más interesante parece, sin embargo, que nos detengamos en diferentes versiones del Quijote para afinar el análisis y comparar soluciones lingüísticas variadas. Y he elegido precisamente un episodio como el de los molinos de viento porque poco morcilleo cabría esperar, por muy separadas que estén en el tiempo y difieran sus contextos de producción y destinatarios, ante pasaje tan célebre, pero sí hay sutiles diferencias de las que obtener sugestiones para el estudio. En la siguiente tabla, he indicado las supresiones con el signo [0] y las modificaciones y adiciones entre corchetes, además de disponer en paralelo, en la medida de lo posible, los pasajes coincidentes, para así facilitar el cotejo:

Texto literario
Don Quijote de la
Mancha
(Cervantes
1998: 94-96)
-La ventura va
guiando nuestras co-
sas mejor de lo que
acertáramos a desear;
porque ves allí, amigo
Sancho Panza, donde
se descubren treinta o
pocos más desaforados
gigantes, con quien
pienso hacer batalla
y quitarles a todos las
vidas, con cuyos des-
pojos comenzaremos a
enriquecer, que esta es
buena guerra, y es gran
servicio de Dios quitar
tan mala simiente de
sobre la faz de la tierra.

Q

\section{Texto fílmico 1 Don Quijote de la Mancha} (R. Gil, 1947)

- La ventura va guiando nuestras cosas mejor de lo que acertáramos a desear; porque ves allí, amigo Sancho Panza, [0] treinta o pocos más desaforados gigantes; con [ellos] pienso [entablar] batalla y quitarles a todos [la vida].

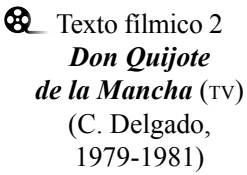

8. Texto fílmico 2 Don Quijote de la Mancha (TV)

(C. Delgado, 1979-1981)

- La [a]ventura [nos guía] mejor de lo que acertáramos a desear, [Sancho]; [pues con esos] desaforados gigantes

[entraré en] batalla,

[que es buen] servicio [0] quitar tan mala simiente [0] de la tierra.
(82) Texto fílmico 3 El Quijote de Miguel de Cervantes (TV)

(M. Gutiérrez

Aragón, 1991)

- i Mira, Sancho, contempla lo que tenemos ahí delante!] La [fortuna] va guiando nuestras cosas mejor [aún] de lo que [deseáramos]; porque ves allí, amigo [0], [más de treinta] desaforados gigantes.

[Ahora mismo] pienso [entrar en] batalla [con ellos] y quitarles [0] las vidas [para enriquecernos con sus] despojos [y arrebatarles sus reinos si es que poseen alguno].

- [Muy bien, señor, 
—Qué gigantes? -dijo Sancho Panza.

-Aquellos que allí ves —respondió su amo-, de los brazos largos, que los suelen tener algunos de casi dos leguas.

- Mire vuestra merced -respondió Sancho- que aquellos que allí se parecen no son gigantes, sino molinos de viento, y lo que en ellos parecen brazos son las aspas, que, volteadas del viento, hacen andar la piedra del molino.

-Bien parece —respondió don Quijoteque no estás cursado en esto de las aventuras: ellos son gigantes; y si tienes miedo quítate de ahí, y ponte en oración en el espacio que yo voy a entrar con ellos en fiera y desigual batalla.

$\mathrm{Y}$, diciendo esto, dio de espuelas a su caballo Rocinante, sin atender a las voces que su escudero Sancho le daba, advirtiéndole que sin duda alguna eran molinos de viento, y no gigantes, aquellos que iba a acometer. Pero él iba tan puesto en que eran gigantes, que ni oía las voces de su escudero Sancho, ni echaba de ver, aunque estaba ya bien cerca, lo que eran, antes iba diciendo en voces altas:

-Non fuyades, cobardes y viles criaturas, que un solo caballero es el que os acomete.
—QQué gigantes?

-Aquellos que allí ves [con] los brazos largos [0] de casi dos leguas.

-Mire vuestra merced que aquellos que all[á] se [a]parecen no son gigantes, sino molinos de viento, y lo que en ellos parecen brazos son las aspas.

-Bien parece que no estás cursado en esto de las aventuras: ellos son gigantes; y si tienes miedo quítate de ahí, y ponte en oración, [0] que yo voy a entrar con ellos en fiera y desigual batalla.

[-¡Deténgase vuestra merced, ah, que no son gigantes!]

[-No h]uyades, cobardes y viles criaturas, que un solo caballero es el que os acomete.
—QQué gigantes?

muy bien. ¿Y a] qué gigantes [se refiere?

-Aquellos que [0] ves de [largos brazos], que los suelen tener [0] casi [de] dos leguas.

- Mire vuestra merced que no son gigantes, sino molinos de viento, y lo que [0] parecen brazos son las aspas que [0] [mueven] la piedra del molino.

- [0] No [sabes nada de] aventuras: [0] son gigantes; [0] si tienes miedo quítate de ahí; [0] voy a entrar con[tra] ellos en fiera y desigual batalla.

[*Estos dos últimos turnos están reubicados tras el «No huyáis...»]

[-No huyáis], cobardes y viles criaturas, que un solo caballero es el que os acomete.
— ¿Eh? A] aquellos que [ves allí.

- ¿Allí?

-A aquellos cuya soberbia es mayor aún que su estatura y que agitan los cielos levantando una tempestad de viento y furor. ¡Aunque mováis más de cien brazos, os rendirá mi espada! Mira cuán largos tienen los brazos: algunos los tienen de más de] dos leguas. [Esta es buena batalla, Sancho]. Gran servicio [a] Dios es quitar [la] mala simiente de [0] la faz de la tierra. [¡Bruciferno! ¡Carmadón! ¡Nabor el bello! ¡Taliarán! ¡Ternurón el malo! ¡Anfeón! ¡Carpatracio! ¡Bronastor el orgulloso!]

-[Señor,] no son gigantes, y lo que [0] parecen brazos son las aspas. [¡Señor!]

-Calla, Sancho, [y prepara a Rocinante. Apresúrate, amigo.

-Señor, son molinos].

- Si tienes miedo, [quédate] y ponte en oración.

- No es miedo, señor. Verá... lo que yo digo...]

-Yo voy a entrar con ellos en fiera $y$ desigual batalla.

- [Preste atención, vuestra merced: con todos mis respetos, son solo molinos que mueve el viento, señor. Son molinos. 
Levantóse en esto un poco de viento, y las grandes aspas comenzaron a moverse, lo cual visto por don Quijote, dijo:

-Pues aunque mováis más brazos que los del gigante Briareo, me lo habéis de pagar.

$\mathrm{Y}$ en diciendo esto, y encomendándose de todo corazón a su señora Dulcinea, pidiéndole que en tal trance le socorriese, bien cubierto de su rodela, con la lanza en el ristre, arremetió a todo el galope de Rocinante y embistió con el primero molino que estaba delante $[. .$.$] .$

— ¿Válame Dios! - dijo Sancho- ¿No le dije yo a vuestra merced que mirase bien lo que hacía, que no eran sino molinos de viento, y no lo podía ignorar sino quien llevase otros tales en la cabeza?

-Calla, amigo Sancho - respondió don Quijote-, que las cosas de la guerra más que otras están sujetas a continua mudanza; cuanto más, que yo pienso, y es así verdad, que aquel sabio Frestón que me robó el aposento y los libros ha vuelto estos gigantes en molinos, por quitarme la gloria de su vencimiento: tal es la enemistad que me tiene; mas al cabo han de poder
Pues aunque mováis más brazos que los del gigante Briareo, me 1[as] habéis de pagar.

[iOh, Dulcinea del Toboso, socorredme en este trance!]

— ¡Vál[g]ame Dios! ¿No le dije [0] a vuestra merced [0] que [0] eran [0] molinos de viento, y [que] no lo podía ignorar sino quien llevase otros tales en la cabeza?

-Calla [0],

que yo pienso [0]

que [el] sabio Frestón

ha vuelto estos gigantes en molinos [para] quitarme la gloria de su vencimiento;

mas [0] han de poder
Pues aunque mováis más brazos que los del gigante Briareo, me lo habéis de pagar.

- [0] [iMi señor don Quijote!] ¿No [os] dije [0] que [0] eran [0] molinos de viento y no [gigantes]?

-Calla, amigo Sancho, que las cosas de la guerra más que otras están sujetas a continua mudanza;

[porque] el sabio Frestón

[0] [ha transformado esos] gigantes en molinos [para] quitarme la gloria de [vencerlos]: tal es la enemistad que me tiene.
-Son gigantes].

[Socorredme, señora mía Dulcinea]. ¡Non fuyades, cobardes y viles criaturas, que un solo caballero es [quien] os acomete!

- [0] [Señor... señor, ya] le dije [0] que mirase bien lo que hacía, [pero] vuestra merced [no quiso escucharme. Levántese. Levántese].

-Calla, [0] Sancho, [calla. ¿Sabes lo que pienso?

—QQué?]

- [Que el malvado Frestón ha intervenido en esto. ¡Quedas avisado, Frestón!]

[De nada han de valer 


$$
\begin{array}{l|l}
\text { poco sus malas artes } & \text { poco sus malas artes } \\
\text { contra la bondad de mi } & \begin{array}{l}
\text { contra la bondad de mi } \\
\text { espada. }
\end{array} \\
\text { espada. } & \text {-Dios lo haga como } \\
\text { puede lo haga como - respondió } & \text { puede. } \\
\text { Sancho Panza. } &
\end{array}
$$

tus] malas artes contra la bondad de $\mathrm{mi}$ espada.

Comencemos por lo que presentan en común: no se trata, en ninguno de los tres casos, de adaptaciones que busquen una visión personalísima del texto o pretendan imprimir sello «autoral» alguno, como las de Orson Welles, Terry Gilliam (las dos inacabadas, por cierto, aunque una fuera reconstruida en 1992 y la segunda vivificada recientemente) o Albert Serra, sino de operaciones de filiación difusora del texto cervantino, y puede apreciarse que rescatan de él, en consecuencia, numerosas líneas de diálogo, en muchos casos sin variación alguna, y las de Gil y Gutiérrez Aragón aprovechan hábilmente alusiones de la voz narrativa para transformar lo diegético en mimético y añadir así alguna réplica más. Me refiero a «las voces que su escudero Sancho le daba» y el «encomendándose de todo corazón a su señora Dulcinea», transformadas ambas en estilo directo, igual que sucede en la de Cruz Delgado justo después de esta aventura de los molinos con el «allí decía don Quijote que no era posible dejar de hallarse muchas y diversas aventuras» (Cervantes 1998: 96). La solución aporta dinamismo y permite trufar verbalmente un episodio que destaca por la acción.

Las versiones de Gil y Cruz Delgado, según se advierte muy fácilmente de una sola mirada, son las que más han «aligerado» el texto cervantino, y operan más por omisión que modernizando. De «simple síntesis» a cargo de Abad Ojuel, más que de «adaptación» en sentido estricto hablaba Gil (Vilches 1998: 215-216; Herranz 2005: 54; España 2007: 66), y Criado de Val, que colaboró en el guion de la segunda, declaraba que «hay que respetar lo que está en la obra original, pero reduciéndolo. No podemos pensar en esos larguísimos parlamentos, que van en contra de la esencia misma de los dibujos animados» (1979: 31). Independientemente de que simpaticemos o no con sus soluciones (por no decir con lo que ideológicamente pueda traslucir la primera de las adaptaciones, como veremos enseguida), es innegable que hay en ello cierta destreza al preferirse, por ejemplo, un «que eran molinos» en lugar de un «que no eran sino molinos», y aprovechar, además, ese polivalente «que» para completar el período tras la omisión del «que mirase bien lo que hacía». Este tipo de recursos, sencillísimos en su pulcritud, no delatan excesiva creatividad pero permiten al menos que no se generen incoherencias (al afectar a la sintaxis y no al léxico) como alguna que observamos en el Lazarillo de Ardavín, y lo menciono porque esa era otra versión de filiación, en cierto modo, «pedagógica». 
En lo que sí difieren notablemente esas dos primeras versiones que he presentado en la tabla, es en el mantenimiento, cómo no, de una de las menciones a Dios y del «ponte en oración» en la adaptación de Gil, mientras que la opción animada elimina «Dios» nada menos que tres veces y no duda tampoco en omitir la alusión al rezo. No se trata de una radical laicización, pues he detectado que en otros capítulos sí se cita, pero es sintomático del nuevo contexto de producción que el realce católico del texto en 1947 se ha trocado ya en plena transición democrática por un evidente efecto atenuador.

Los artífices del guion de la primera, Gil (Vilches 1998: 217) y Abad Ojuel (Alcaraz 1998: 222), en sus tempranas declaraciones a la revista Radiocinema, se encomiendan ellos mismos a la divinidad, y ya en la práctica del filme se oye un solemne «Gloria» acompañando una y otra vez a la música; se añaden al texto cervantino, por ejemplo, un «Mañana amanecerá Dios y será ocasión de impedirlo» en boca, claro, del cura y, a los pocos instantes, un «Dios nos dé buena mañana» pero de la sobrina; y oímos al protagonista rezar un «Ave María» en su penitencia de Sierra Morena, así que en el componente verbal demostraban que era la suya una adaptación bien devota. Si a ello sumamos que para Abad Ojuel «solo entre españoles podemos dar una versión certera y entrañable de Don Quijote» (Alcaraz 1998: 221), completamos el nacional-catolicismo a flor de piel que caracteriza al filme y que una productora como Cifesa abanderó sobradamente con la connivencia de la crítica porque, como se protestaba con sorna desde las páginas de Cinema a propósito de la película, «según parece hay una especie de "deber nacional" de poner[la] por las nubes» (Pérez Bowie 2004: 149).

Hechas estas precisiones, se entiende también que, por citar otro factor de análisis que nos incumbe aquí, en la selección de los discursos no sea el de la «Edad Dorada» (en la que no existían las palabras «tuyo y mío») el que emerja, sino el de las armas y las letras, y eligiéndose, de entre todo lo que ofrecía el texto cervantino, la «oportuna» mención de que «las primeras buenas nuevas que tuvo el mundo y tuvieron los hombres fueron las que dieron los ángeles la noche que fue nuestro día, cuando cantaron en los aires: "Gloria sea en las alturas, y paz en la tierra a los hombres de buena voluntad"» (Cervantes 1998: 443), pasaje este del que no se modifica absolutamente nada y que Mañas Martínez ha explicado como paradigma de una «abierta manipulación ideológica» en la que, por cierto, afloran las armas pero «de las letras no hay ni rastro» (2006: 87).

Despojada de estas operaciones tan marcadas por el contexto, y con el propósito matriz, según uno de sus artífices, Santiago Romagosa, de dirigirse «a aquellos que todavía no habían tomado contacto con el Quijote, incitándoles seguramente a realizar una primera lectura de nuestra inmortal novela» (Payán 2005: 142), la serie de animación de Cruz Delgado se encomienda a operaciones modernizadoras que afectan al léxico («lengua quieta» por «lengua queda») y a lo gramatical («pagarle» 
por «pagalle»), ejemplos extraídos del capítulo 2, en el que don Quijote es armado caballero, donde aflora asimismo la conversión de pasajes monológicos en dialógicos, con la frecuente interactuación de los animales, que se erigen en circunstanciales protagonistas, sobre todo, el galgo, las cabalgaduras y un recurrente cuervo que aparece también como divertido espectador de la batalla contra los molinos. Este curioso realce de los animales, que, naturalmente, guarda relación con el público al que está destinada principalmente la serie animada y aporta un efecto humorístico a modo de «gags» (Criado de Val 1979: 31), está emparentado asimismo con lo verbal por el hecho de que llegan a ser oyentes de las palabras emitidas por los personajes y se les interpela a menudo, de forma que cumplen una función dinamizadora.

En la que quiero detenerme, y por eso la he reservado hasta ahora en el cotejo de las tres versiones, es en la serie de Gutiérrez Aragón por sus amagos geniales de creatividad. Y digo «amagos» porque se trata de la obra magna de nuestra literatura y eso no lo pierde de vista el realizador, que se pone al servicio, además, del ente público y su propósito divulgador (Herranz 2005: 72-79). Conviene antes aclarar que Cela, en realidad, aunque aparezca acreditado, no es su guionista (solo ha dejado como superficial impronta la división en «trancos»): según Gutiérrez Aragón, el literato se limitó a enviar «hojas del libro prendidas con clips en un simulacro de adaptación» (2015: 136), lo cual, naturalmente, no le valía, porque para él, «obsesionado con la transmigración de las palabras» (2015: 140), la clave de la adaptación era el componente verbal. En el precioso texto del que acabo de extraer la cita, A los actores, insiste una y otra vez en ello, y si nos fijamos de nuevo en la tabla, hay en su versión abundantes elementos relacionados con lo que el realizador denomina, acudiendo a Austin, «performatividad» (2015: 145), ya que «el habla de don Quijote es performativa, creativa y creadora, y tan bella como adictiva. Es acción, como lo es, sin que nadie lo dude, la imagen en movimiento» (2015: 140-141). Abundan así, en su adaptación del citado episodio de los molinos, los imperativos, las interrogaciones y las interpelaciones directas, tanto extraídas del texto literario como de nueva creación, y aprovecha con pericia varios parlamentos más extensos para quebrarlos e incorporar diálogos (es así, de las tres versiones, la que más multiplica los turnos).

Es, además, la única de las tres adaptaciones que se atreve a mantener, sin aspiración, el «non fuyades», y es que hay en la serie una decidida voluntad de recuperar elementos estilísticos del texto literario como el políptoton, de nuevo con mantenimiento de $F$ - («fecho/ficieron/ficisteis»), o la paronomasia (el divertido juego entre «homicidio/homecillo»), que requieren la conservación de rasgos arcaizantes. Lo explica así el propio realizador:

Con la inestimable ayuda del escritor y cinéfilo Fernando Corrugedo, se encontró una fórmula por la que don Quijote siguiera hablando «en antiguo» — una manera 
de hablar ya pasada incluso en su época-, con sus «fermosos», «fechos», «facer»..., mientras que los otros personajes hablarían en un lenguaje más sencillo, pero sin utilizar términos que no pertenecieran a su tiempo (2015: 139).

Se obra de esta forma porque en los añadidos de creación propia no se escatima tampoco en ese tipo de juegos verbales con los que he ejemplificado. Así, por citar casos de otros personajes, Cardenio dirá «Nada más me gustaría que daros ese gusto», y el mayor logro de esta tendencia reside, creo, en el modo como se resuelve el reencuentro cuádruple de la venta, culminando el «Venciste, hermosa Dorotea, venciste» de Cervantes (1998: 429) con un espléndido «y puesto que Luscinda encontró lo que quería, justo es que yo quiera lo que encuentro», perfecta resolución por vía lingüística (e incluso, en particular, quiasmática) del conflicto que se presenta en ese momento, y que ya no debe resolverse echando mano de la espada, sino de la elocuencia.

Claro que a poco que uno esté familiarizado con los textos áureos, y a pesar de los indudables esfuerzos de los adaptadores por acuñar el lenguaje de la época, se detectan leves anomalías, más en giros y locuciones que en el propio léxico, en pasajes algo más extensos como este (con tímido remedo de aquel «rubicundo Apolo», de aires gongorinos, que ya figuraba en Cervantes):

Oh, tú, sol, que ya estás ensillando tus caballos para madrugar y correr a ver a mi señora, te suplico que la saludes de mi parte, pero ¡cuidado con besarla en el rostro, porque quedaré tan furioso como enamorado!

No obstante, y en descargo de los guionistas, he de admitir que a veces he consultado el texto literario para comprobar si los diálogos eran de cosecha propia o extraídos de Cervantes, y un análisis más exhaustivo podría deparar bastantes sorpresas sobre lo que añadieron ellos y su efectividad, dada la armónica convivencia con lo que se mantiene de la fuente ${ }^{12}$.

Su retorno al texto, pero ya el de 1615, con El caballero don Quijote (2002), que a pesar de contar con actores distintos puede verse como la prolongación natural de la truncada serie en forma de largometraje, ofrece un nuevo punto de interés en lo que respecta a lo verbal: parece que su eje selectivo respecto a la obra literaria se encuentra precisamente (junto a lo metafictivo) en dicho componente

12 Y no olvidemos, respecto a la participación de Fernando Rey como don Quijote, que «la inconfundible voz dramática del actor, capaz de controlar incluso sus derivas más retóricas, contribuye en buena medida a ese efecto de verosimilitud» (Hernández 2005: 19), y otro tanto creo que podría decirse del Juan Luis Galiardo que lo encarna en la siguiente incursión cervantina de Gutiérrez Aragón, por más que sea la suya una interpretación de muy diferente registro, pero idónea para atemperar posibles excesos que darían al traste con el elaborado trabajo verbal. 
lingüístico, tal vez liberado ya del prurito de antologar las aventuras más conocidas de la primera parte del Quijote en la serie televisiva. Durante el proceso de elaboración, ya señalaba el realizador que «va a ser una película en la que el diálogo va a tener tanto que ver como la acción» (Kercher 2002: 131), y una de sus claves es la fascinación que la faceta discursiva de don Quijote despierta en Sancho, pues este dirá (¡al rucio!) en los primeros compases « ¿Cómo habla! ¡Oye cómo habla!», toda una declaración de intenciones, a través del personaje, de su realizador. Para Gutiérrez Aragón, en la obra cervantina «don Quijote habla para Sancho, $\mathrm{y}$, con sus maneras de hablar, ya está creando expectación, como cualquier divo con solo salir al escenario» (2015: 146). ¿Y qué estaba oyendo el escudero para reaccionar así? Este precioso discurso sobre los signos del amor:

\section{Texto literario \\ Don Quijote de la Mancha \\ (Cervantes 1998: 700-701)}

\author{
8 Texto fílmico \\ El caballero don Quijote \\ (M. Gutiérrez Aragón, 2002)
}

Dichoso tú, sobre todos los escuderos del mundo, que vas a ver a la mejor dama que fuera cortejada por caballero. Anda, hijo, y no te turbes cuando vieres la luz de su hermosura. Cuando estés delante de mi señora, mira bien y fíjate en los detalles: si se desasosiega y cambia de color escuchando mi nombre, o si se pone ahora sobre un pie, y ahora sobre otro, al oír tu embajada; si estuviera sentada, mira si se ahueca como si no cupiera en el cojín; escucha si repite su respuesta dos o tres veces. Ah, y mira si se lleva la mano al cabello para colocarlo aunque no estuviera desordenado.

[0]

Porque, para los amantes, estos signos son certísimos correos que traen la nueva de lo que acontece allá, en el interior del alma.

Se trata de soluciones lingüísticas muy hábiles para sintetizar, alterando la disposición, recomponiendo y modernizando ocasionalmente con los fragmentos 
de engarce. Y lo divertido es que Sancho, aunque fascinado, sigue sin entenderlo, porque replica: «Donde no hay tocinos, no hay estacas», único refrán de los que enfila en el texto literario que se recupera en el filme, y, además, sin «problematizarse» su idoneidad (como sí prefiere Cervantes), pues queda aislado y cobra así un efecto de absurdo nada desdeñable, de acuerdo con lo que propone la película.

Muestra de este interés por lo discursivo, es que son muchas las disertaciones extensas, como la que acabo de citar, que selecciona y transforma, y es de notar «la oportunidad con que están presentados ciertos parlamentos, como las diferentes exhortaciones de don Quijote a Sancho» (Merino 2003: s.p.), entre las cuales destaca la que versa sobre la libertad que pronuncia el caballero en el capítulo LVIII, donde varias de las modificaciones responden a exigencias funcionales y se agiliza el discurso de forma extraordinaria.

Y si ponemos mientes no ya en estos parlamentos extensos tan bien resueltos, sino en segmentos más breves, muy acertados parecen, por ejemplo, el «tonto forrado de bobo» que sustituye al «tonto, aforrado de lo mismo, con no sé qué ribetes de malicioso y de bellaco» (1998: 1104), que vuelve a mostrar cómo la síntesis, con mantenimiento parcial del léxico y giro en torno al concepto matriz, funciona armónicamente; o el logrado «que muge y se mueve» que se inventa para que lo diga Sancho cuando contempla el mar, consecuente con la conocida ósmosis entre caballero y escudero que se produce en el texto cervantino y que había destacado Gutiérrez Aragón en una entrevista como uno de los factores que más le atrayeron de la segunda parte del Quijote (Kercher 2002: 131), rasgo que se extiende, naturalmente, también a lo verbal, de ahí el hallazgo expresivo de Sancho.

\section{Calas en las adaptaciones del teatro Áureo}

Resulta útil, como punto de partida, atender a la tipología que establece Pérez Bowie (2001) en un trabajo sobre el tratamiento del verso en las adaptaciones teatrales al cine, dado que este particular nos afecta en alto grado a la hora de tasar el componente verbal en las que se efectuaron a partir de textos del Siglo de Oro. Una vez descartada «la conservación del verso dentro de un contexto de teatralidad explícita», que atañe a obras como La venganza de don Mendo y Angelina o el honor de un brigadier (2001: 325-329) que rebasan nuestro objeto de estudio, nos interesan aquí «la prosificación del verso», categoría que Pérez Bowie explica deteniéndose en la Fuenteovejuna de 1947 (2001: 323-325), y «la naturalización del verso», con El perro del hortelano de 1995 como principal exponente (2001: 329-332).

Si trasladar el verso a la relativa «neutralidad» de la prosa o, por el contrario, mantenerlo intacto en un alto porcentaje, pero «mediante la creación de un contexto en el que resulte creíble» y responda «a los esquemas tonales habituales» 
(2001: 329) son operaciones de construcción del guion muy diferentes, persiguen, sin embargo, el común objetivo de que los diálogos fluyan sin que el espectador perciba un brusco «efecto de extrañamiento». Que el propósito se logre, depende de factores muy diversos (al frente de los cuales figuran, claro, la labor de los actores y la predisposición positiva del receptor), y es probable que el segundo caso requiera, además, un cierto período de «aclimatación», según atestiguan las experiencias con El perro del hortelano y La dama boba ${ }^{13}$, para asumir como algo «natural» que los personajes hablen en verso en una película.

Tal vez habría que añadir un tipo mixto como el que propone Mario Camus, con guion de Antonio Drove, en La leyenda del Alcalde de Zalamea (1972), y si atendemos al modo en que se practican simultáneamente las operaciones de prosificación y de mantenimiento del verso, la impresión es que, sorprendentemente, un filme muy inferior como El alcalde de Zalamea (1954) de José Gutiérrez Maesso resuelve de manera más satisfactoria la elaboración de los diálogos. La razón, creo, reside en dos circunstancias muy reveladoras para nuestro cometido: en esa versión más antigua, la sencilla prosificación que se practica permite que los necesarios añadidos no disuenen respecto a lo conservado del texto literario; en cambio, en un filme bastante más logrado por múltiples razones ${ }^{14}$ como el de Camus, la alternancia (no siempre justificada por razones argumentales ni por «decoro práctico») de segmentos estilizados con intervenciones mucho más coloquiales, puede resultar incoherente. Si en varias secuencias del filme no se aprecian especialmente estas disonancias, y tiene razón Utrera al destacar «la especial protección que Drove/Camus tienen para el mantenimiento del verso en determinadas escenas y en conocidas situaciones haciendo perder engolamiento en su dicción y otorgando naturalidad expresiva a los diferentes metros recitados» (2007: 57) $)^{15}$, llega un momento en que, inevitablemente, se le notan las

13 Y que afecta también al propio proceso de elaboración del filme; en este segundo caso, contamos con el testimonio de Manuel Iborra, su realizador, quien recordaba que «la primera semana de rodaje los técnicos escuchaban los diálogos de los actores como si estuvieran haciendo una película en checoslovaco», y a partir de la tercera semana empezó a cambiar esa percepción (2011: 139).

14 Son muy acertados, por ejemplo, el recurso del ciego que va cantando la leyenda (de ahí el título) o la apuesta por la no linealidad temporal, que delatan gran creatividad, y la película fue bien acogida por la crítica (Sánchez Noriega 1998: 165-166); la de Gutiérrez Maesso, que no arranca mal incidiendo en elementos humorísticos y festivos, empieza a malograrse cuando se produce el rapto y precipita, además, la resolución del conflicto, presentada con cierta torpeza.

$15 \mathrm{Si}$ atendemos a cuestiones taxonómicas, Utrera indica que, «frente al desprecio habitual por el verso en la mayoría de las adaptaciones teatrales a la pantalla, frente a las excepciones de la integridad estrófica en la película, estamos ante una eficaz "tercera vía", peculiar modelo cinematográfico de la época, donde una cumplida selección de metros dignamente enunciados se integra en una comunicación audiovisual capaz de llegar a todo tipo de espectadores de un medio, 
costuras. Esto se debe a una segunda circunstancia distintiva: Camus adapta dos textos, los dramas homónimos de Calderón y el atribuido a Lope (sobre cuya autoría se han presentado serias dudas con posterioridad), y no solo uno, el más conocido de Calderón, como prefirió Gutiérrez Maesso. Al fusionarse dos obras, cuya versificación es bien distinta, y añadirse goznes para conjugarlas, se perciben ciertos efectos distorsionadores en el componente verbal, cuya estilización no es homogénea, como en este ejemplo de mixtura de textos en tres secuencias contiguas:

\section{Texto literario 1 \\ El alcalde de Zalamea}

(Calderón de la Barca 1987: 197-198)

SARgento:

¿No decías que villanas

nunca tenían belleza?

CAPITÁN:

$\mathrm{Y}$ aun aquesa confianza me mató, porque el que piensa

que va a un peligro, ya va

prevenido a la defensa;

quien va a una seguridad,

es el que más riesgo lleva

por la novedad que halla,

si acaso un peligro encuentra.

Pensé hallar una villana.

Si hallé una deidad, ¿no era

preciso que peligrase

en mi misma inadvertencia?

En toda mi vida vi

más divina, más perfecta

hermosura. ¡Ay, Rebolledo!,

no sé qué hiciera por verla.

\section{Texto fílmico \\ La leyenda del alcalde de Zalamea}

(M. Camus, 1972)

SARgEnto:

¿No decías que villanas

nunca tenían belleza?

CAPITÁN:

$\mathrm{Y}$ aun aquesa confianza

me mató, porque el que piensa

que va a un peligro ya va

prevenido a la defensa.

[0]

Pensé hallar una villana;

si hallé una deidad, ¿no era

preciso que peligrase

en mi misma inadvertencia?

[¿Dónde vas?

SARGENTO: Lo intentaré arreglar].

GINESA: Soy yo.

ISABEL: ¿Qué quieres? ¿Se ha levantado ya don

Lope?

GINESA: Está con tu padre en el patio.

ISABEL: ¿Has preparado ya la cena?

el cinematográfico o televisivo, que no debe estar reñido con la tradición de un teatro popular y nacional» (2007: 57), mientras que Sánchez Noriega se refiere a una «naturalización del drama, al que se proporciona realismo - dicción del verso muy poco marcada, interpretación realista de personajes, insertos de secuencia documental y de primeros planos de gentes concretas- y se cuida mucho su verosimilitud» (1998: 161), de manera que podría considerarse un tipo mixto para un caso como este de La leyenda del Alcalde de Zalamea, o plantearse su inclusión en la categoría propuesta por Pérez Bowie de «naturalización del verso». 
Texto literario 2

\section{El alcalde de Zalamea}

(Lope de Vega, atrib., 1998: 412)

DON JuAn:

Con el amor y el deseo

vengo luchando, ángel mío:

el deseo para veros,

y el amor para serviros.

Don Diego:

También pudierais oír que mi amor es infinito; que son relojes del alma, bella Leonor, los suspiros.

LEONOR

¡Qué lisonjeros que estáis!

DON JuAn:

Mejor nos diréis perdidos.
GiNESA: Sí, me han dado un recado para ti.

ISABEL: ¿Quién, mi padre?

GinesA: El capitán quiere verte. Está abajo el sargento esperando que le digas algo.

ISABEL: No quiero saber nada del capitán. Bastantes disgustos ha dado ya. Ginesa, ¿tú por qué tienes que llevar recados? Dile que se marche inmediatamente y que no vuelva, no le vaya a ver padre y haya otra vez pelea.

LEONOR: ¿Qué pasa?

INÉs: ¿Qué pasa?

ISABEL: Nada.

LEONOR: Ah, es que nos habíamos asustado.

INÉs: Vamos a nuestro cuarto.

LEONOR: No estamos haciendo nada, no te vayas a creer.

INÉs: Entra.

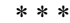

DON JUAN:

Con el amor y el deseo vengo luchando, ángel mío:

el deseo para veros,

y el amor para serviros.

Don Diego:

También pudierais oír que mi amor es infinito; que son relojes del alma, bella Leonor, los suspiros.

LEONOR:

¡Qué lisonjeros [0] estáis!

Don JuAn:

Mejor nos diréis perdidos.

El tránsito de los versos del capitán (con cuña prosaica de su secuaz) al diálogo no solo muy coloquial, sino además en castellano moderno, de las hijas, y nuevamente a la estilización del verso en la siguiente secuencia, creo que perjudica al conjunto desde el punto de vista lingüístico, aunque las situaciones comunicativas sean diferentes. En cambio, nótese cómo se procede en el filme de 1954 desde su primer diálogo extenso (véase tabla en p. 210).

Gutiérrez Maesso, en su síntesis y prosificación, obra de forma homogénea, sin mezclar códigos, porque efectúa dos operaciones bien conjugadas: por una parte, toma un concepto o idea contenidos en los versos de Calderón y los desarrolla en prosa; por otra, rescata ciertos términos (o incluso versos completos en 


\section{Texto literario \\ El alcalde de Zalamea}

(Calderón de la Barca 1987: 145-149)

Nuño:

¿Por qué, si de Isabel eres

tan firme y rendido amante,

a su padre no la pides?

Pues con esto, tú y su padre

remediaréis de una vez

entrambas necesidades:

tú comerás, y él hará

hidalgos sus nietos.

Don Mendo:

No hables

más [Nuño], calla. ¿Dineros

tanto habían de postrarme

que a un hombre llano por fuerza

había de admitir [?]

Nuño:

Pues antes

pensé que ser hombre llano,

para suegro, era importante;

pues de otros dicen que son

tropezones en que caen

los yernos. Y si no has

de casarte, ¿por qué haces

tantos extremos de amor?

Don Mendo:

¿Pues no hay, sin que yo me case,

Huelgas en Burgos, adonde

llevarla, cuando me enfade?

Mira, si acaso la ves.

Nuño:

Temo, si acierta a mirarme.

Pero Crespo..

Don Mendo:

¿Qué ha de hacerte,

siendo mi criado, nadie?

Haz lo que manda tu amo.

Nuño:

Sí haré, aunque no he de sentarme

con él a la mesa.

Don Mendo:

Es propio

de los que sirven, refranes.

NuÑo:

Albricias, que con su prima,

Inés a la reja sale.

\section{(2) Texto fílmico}

El alcalde de Zalamea

(J. Gutiérrez Maesso, 1954)

NuÑo: Todos tienen dinero, menos nosotros, pero podríamos tenerlo si tú, que eres tan rendido amante de Isabel, la pidieras en matrimonio.

[0]

Don Mendo: ¿Qué dices? ¿Crees que por faltarme dinero voy a aceptar por suegro a un labrador?

NUÑo: ¿Y por qué no? Los dos saldríais ganando: él haría hidalgos a sus nietos, y tú comerías. Y yo también...

Don Mendo: Yo no puedo manchar la ejecutoria que me dejó mi padre.

NUÑo: ¿Entonces no la cortejas para casarte?

[0]

Don Mendo: Ya hay un monasterio de las Huelgas en Burgos donde encerrarla cuando me moleste.

$[0]$

Ella es [señala hacia las labradoras]. Quédate guardándome las espaldas.

NuÑo: ¿Y a mí quién me las guarda?

Don Mendo: Mi ejecutoria. Nadie se atreverá a pegar al criado de tal amo.

INÉs: ¡Uy! Ahí viene don Mendo como siempre. Vamos.

IsABEL: Anda, hay que llegar antes a la puerta. No te rías, Inés.

[0] 
Don Mendo:

$[\ldots]$

Hasta aqueste mismo instante jurara yo, a fe de hidalgo,

-que es juramento inviolableque no había amanecido; mas ¿qué mucho que lo extrañe, hasta que a vuestras auroras segundo día les sale?
Don Mendo: Hubiera jurado a fe de hidalgo que ya la noche se venía, mas al veros de nuevo, la aurora ha aparecido en el cielo.

otros ejemplos) que, al quedar aislados, no disuenan rítmicamente, y los «envuelve» bien en esa misma prosa ${ }^{16}$.

Por último, para ejemplificar cómo se produce, según la mencionada casuística de Pérez Bowie, la «naturalización del verso», podría acudirse a las soluciones de El perro del hortelano o de La dama boba, y es de notar que el mantenimiento del verso en un contexto que no remita a lo teatral (apuesta, desde luego, arriesgada) se ha encauzado generalmente con textos de gran comicidad y, sobre todo, asunto amoroso, como ha sucedido en sus principales precedentes foráneos, Cyrano de Bergerac (Jean-Paul Rappeneau, 1990) y Mucho ruido y pocas nueces (Kenneth Branagh, 1993). Esto debería tomarse en consideración a la hora de analizarlas junto a la decisiva elección transgresora de los personajes femeninos en el caso de lo que propusieron Pilar Miró y Manuel Iborra (y este último prefiriendo, además, que la madre, encarnada por Verónica Forqué, fuera quien llevara la voz cantante, frente a lo que eligió Lope), elementos todos ellos que podrían servir de «amortiguador» para los peligros de que el público rechace el verso.

He elegido la siguiente secuencia del filme de Pilar Miró para que se tenga en cuenta, de acuerdo con la tipología de Pérez Bowie, que los personajes hablan como en el teatro pero no están, desde luego, en una localización teatral, y es necesario que ambos componentes encajen adecuadamente para que se produzca la «naturalización». Se trata de una reubicación espacial aprovechando la indefinición de las acotaciones de Lope (Pérez Sierra 1995: 110-111), de modo que nos encontramos nada menos que con un paseo en góndola, y añado al cotejo la versión televisiva de 1981, que sí discurre, claro, en interiores, a cargo de Cayetano Luca de Tena:

16 Eso sí, en algunas intervenciones del personaje de Pedro Crespo puede percibirse homogeneidad en las soluciones prosificada y versificada de ambos filmes, porque el intérprete de la segunda versión (Francisco Rabal) no recita ni declama, de modo que los versos podrían pasar por prosa (al menos en sus efectos rítmicos y en la velocidad), como en la secuencia de los consejos que da a su hijo. 


\section{Wexto literario El perro del hortelano}

(Lope de Vega 1970: 117-122)

DiANA:

En fin, Teodoro, ¿tú quieres casarte?

\section{TEODORO:}

Yo no quisiera

hacer cosa sin tu gusto, y créeme que mi ofensa no es tanta como te han dicho; que bien sabes que con lengua de escorpión pintan la envidia y que si Ovidio supiera qué era servir, no en los campos, no en las montañas desiertas pintara su escura casa; que aquí habita y aquí reina.

DiAnA:

Luego ¿no es verdad que quieres a Marcela?

TEODORO:

Bien pudiera

vivir sin Marcela yo.

DiAna:

Pues díceme que por ella pierdes el seso.

TEODORO:

Es tan poco, que no es mucho que le pierda, mas crea vuseñoría que, aunque Marcela merezca esas finezas en mí, no ha habido tantas finezas.

DiAnA:

Pues ¿no le has dicho requiebros tales que engañar pudieran a mujer de más valor?

TEOdoro:

Las palabras poco cuestan.

DiAnA:

¿Qué le has dicho, por mi vida? ¿Cómo, Teodoro, requiebran los hombres a las mujeres?

TeOdoro:

Como quien ama y quien ruega, vistiendo de mil mentiras una verdad, y ésa apenas.

\section{(2) Texto fílmico 1 \\ El perro del hortelano}

(P. Miró, 1995)

DiAnA:

En fin, Teodoro, ¿tú quieres casarte?

\section{TEODORO:}

Yo no quisiera

hacer cosa sin tu gusto,

y créeme que mi ofensa

no es tanta como te han dicho;

que bien sabes que con lengua

de escorpión pintan la envidia

y que si Ovidio supiera

qué era servir, no en los campos, no en las montañas desiertas

pintara su escura casa;

que aquí habita y aquí reina.

DiAnA:

Luego ¿no es verdad que quieres a Marcela?

TeOdoro:

Bien pudiera

vivir sin Marcela yo.

DianA:

Pues díceme que por ella pierdes el seso.

TeOdoro:

Es tan poco

que no es mucho que le pierda mas crea vuseñoría

que, aunque Marcela merezca

esas finezas [de] mí,

no ha habido tantas finezas.

DiAnA:

Pues ¿no le has dicho requiebros tales que engañar pudieran a mujer de más valor?

TEODORO:

Las palabras poco cuestan.

DiAnA:

¿Qué le has dicho, por mi vida? ¿Cómo, Teodoro, requiebran los hombres a las mujeres?

TEODORO:

Como quien ama y quien ruega, vistiendo de mil mentiras una verdad, y esa apenas.
8 Texto fílmico 2

El perro del hortelano (TV)

(C. Luca de Tena, 1981)

DiAnA:

En fin, Teodoro, ¿tú quieres casarte?

TEODORO:

Yo no quisiera

hacer cosa sin tu gusto, y créeme que mi ofensa no es tanta como te han dicho; que bien sabes que con lengua de escorpión pintan la envidia

[0]

que aquí habita y aquí reina.

Diana:

Luego ¿no es verdad que quieres a Marcela?

TEOdoro:

Bien pudiera

vivir sin Marcela yo.

DiAnA:

Pues díce[n]me que por ella pierdes el seso.

TEOdoro:

Es tan poco,

que no es mucho que le pierda, mas crea vu[e]señoría

que, aunque Marcela merezca esas finezas [de] mí, no ha habido tantas finezas.

Diana:

Pues ¿no le has dicho requiebros tales que engañar pudieran a mujer de más valor?

TEODORO:

Las palabras poco cuestan.

DiANA:

¿Qué le has dicho, por mi vida? ¿Cómo, Teodoro, requiebran los hombres a las mujeres?

TEOdoro:

Como quien ama y quien ruega, vistiendo de mil mentiras una verdad, y esa apenas. 
DiANA:

Sí, pero ¿con qué palabras?

TEODORO:

Extrañamente me aprieta vuseñoría. «Esos ojos (le dije), esas niñas bellas, son luz con que ven los míos» $\mathrm{y}$ «los corales y perlas desa boca celestial...»

DIANA:

¿Celestial?

TEOdoro:

Cosas como éstas

son la cartilla, señora, de quien ama y quien desea.

DiAnA:

Mal gusto tienes, Teodoro; no te espantes de que pierdas hoy el crédito conmigo, porque sé yo que en Marcela hay más defectos que gracias, como la miro más cerca. Sin esto, porque no es limpia, no tengo pocas pendencias con ella..., pero no quiero desenamorarte de ella; que bien pudiera decirte cosa..., pero aquí se quedan sus gracias o sus desgracias; que yo quiero que la quieras y que os caséis en buenhora, mas pues de amador te precias, dame consejo, Teodoro (¡ansí a Marcela poseas!), para aquella amiga mía, que ha días que no sosiega de amores de un hombre humilde, porque si en quererle piensa, ofende su autoridad, y si de quererle deja, pierde el jüicio de celos; que el hombre, que no sospecha tanto amor, anda cobarde, aunque es discreto, con ella.

TEODORO:

¿Yo, señora, sé de amor?

No sé, por Dios, cómo pueda aconsejarte.

DiAnA:

¿No quieres,
DIANA:

Sí, pero ¿con qué palabras?

TEODORO:

Extrañamente me aprieta vuseñoría. «Esos ojos (le dije), esas niñas bellas son luz con que ven los míos» $\mathrm{y}$ «los corales y perlas desa boca celestial...»

Diana:

¿Celestial?

TEOdoro:

Cosas como estas

son la cartilla, señora,

de quien ama y quien desea.

DiAnA:

Mal gusto tienes, Teodoro; no te espantes de que pierdas hoy el crédito conmigo, porque sé yo que en Marcela hay más defectos que gracias, [que yo] la miro más cerca.

Sin esto, porque no es limpia, no tengo pocas pendencias con ella..., pero no quiero desenamorarte de ella; que bien pudiera decirte cosa..., pero aquí se quedan sus gracias o sus desgracias; que yo quiero que la quieras y que os caséis en buenhora, mas pues de amador te precias, dame consejo, Teodoro (i[así] a Marcela poseas!), para aquella amiga mía, que ha días que no sosiega de amores de un hombre humilde, porque si en quererle piensa, ofende su autoridad, y si de quererle deja, pierde el juicio [con los] celos; que el hombre que no sospecha tanto amor anda cobarde, aunque es discreto con ella.

Teodoro:

¿Yo, señora, sé de amor?

No sé, por Dios, cómo pueda aconsejarte.

DiAnA:

¿No quieres,
DiAnA:

Sí, pero ¿con qué palabras?

TEODORO:

Extrañamente me aprieta

vu[e]señoría. «Esos ojos

(le dije), esas niñas bellas, son luz con que ven los míos» $\mathrm{y}$ «los corales y perlas desa boca celestial...»

DiAnA:

¿Celestial?

TEOdoro:

Cosas como estas

son la cartilla, señora,

de quien ama y quien desea.

DiAnA:

Mal gusto tienes, Teodoro;

no te [asustes] de que pierdas hoy el crédito conmigo, porque sé yo que en Marcela hay más defectos que gracias, [porque] la miro más cerca.

Sin esto, porque no es limpia, [tengo no] pocas pendencias con ella..., pero no quiero desenamorarte de ella; que bien pudiera decirte $\operatorname{cosa}[\mathrm{s}] . . .$, pero aquí se quedan sus gracias [y] sus desgracias; que yo quiero que la quieras y que os caséis en buenhora, mas pues de amador te precias, dame consejo, Teodoro (i[así] a Marcela poseas!), para aquella amiga mía, que ha días que no sosiega de amores de un hombre humilde, porque si en quererle piensa, ofende su autoridad, y si de quererle deja, [el juicio pierde] de celos; que el hombre que no sospecha tanto amor anda cobarde, aunque es discreto con ella.

TEOdoro:

¿Yo, señora, sé de amor?

No sé, por Dios, cómo pueda aconsejarte.

DiAnA:

¿No quieres, 
como dices, a Marcela? ¿No le has dicho esos requiebros? Tuvieran lengua las puertas, que ellas dijeran...

TEODORO:

No hay cosa

que decir las puertas puedan.

Diana:

$\mathrm{Ea}$, que ya te sonrojas, $\mathrm{y}$ lo que niega la lengua confiesas con las colores.

TEODORO:

Si ella te lo ha dicho, es necia; una mano le tomé, y no me quedé con ella, que luego se la volví; no sé yo de qué se queja.

Diana:

Sí, pero hay manos que son como la paz de la Iglesia, que siempre vuelven besadas.

TEODORo:

Es necísima Marcela; es verdad que me atreví, pero con mucha vergüenza, a que templase la boca con nieve y con azucenas.

Diana:

¿Con azucenas y nieve?

Huelgo de saber que tiempla ese emplasto el corazón.

Ahora bien, ¿qué me aconsejas?

TEODORO:

Que si esa dama que dices hombre tan bajo desea, $\mathrm{y}$ de quererle resulta a su honor tanta bajeza, haga que con un engaño, sin que la conozca, pueda gozarle.

Diana:

Queda el peligro de presumir que lo entienda. ¿No será mejor matarle?

TEODORO:

De Marco Aurelio se cuenta que dio a su mujer Faustina, para quitarle la pena, sangre de un esgrimidor; como dices, a Marcela? ¿No le has dicho esos requiebros? Tuvieran lengua las puertas, que ellas dijeran...

TEODORo:

No hay cosa

que decir las puertas puedan.

\section{Diana:}

Ea, que ya te sonrojas, y lo que niega la lengua confiesas con las colores.

TEODORO:

Si ella te lo ha dicho, es necia; una mano le tomé,

y no me quedé con ella, que luego se la volví; no sé yo de qué se queja.

\section{Diana:}

Sí, pero hay manos que son como la paz de la Iglesia, que siempre vuelven besadas.

TEODORO:

[Pues es muy necia] Marcela; es verdad que me atreví, pero con mucha vergüenza, a que templase la boca con nieve y con azucenas.

Diana:

¿Con azucenas y nieve? Huelgo de saber que [templa] ese emplasto el corazón. Ahora bien, ¿qué me aconsejas?

TEODORO:

Que si esa dama que dices hombre tan bajo desea, y de quererle resulta a su honor tanta bajeza, haga que con un engaño, sin que la conozca, pueda gozarle.

Diana:

Queda el peligro de presumir que lo entienda. ¿No será mejor matarle?

TeOdoro:

De Marco Aurelio se cuenta que dio a su mujer Faustina para quitarle [una] pena [la] sangre de un [gladiador]; como dices, a Marcela? ¿No le has dicho esos requiebros? Tuvieran lengua las puertas, que ellas dijeran...

TEODORO:

No hay cosa

que decir las puertas puedan.

Diana:

Ea, que ya te sonrojas, y lo que niega la lengua confiesas con $1[0] s$ colores.

TEOdoro:

Si ella te lo ha dicho es necia; una mano le tomé,

y no me quedé con ella, que luego se la volví; no sé yo de qué se queja.

DiAnA:

Sí, pero hay manos que son como [imágenes de] iglesia, que siempre vuelven besadas.

TEODORO:

[Gran embustera es] Marcela; es verdad que me atreví,

[aunque] con mucha vergüenza, a que templase la boca con nieve y con azucenas.

DiAnA:

¿Con azucenas y nieve?

[Me alegra saber] que [templa] ese emplasto el corazón.

Ahora bien, ¿qué me aconsejas?

Teodoro:

Que si esa dama que dices hombre tan bajo desea,

y de quererle resulta

a su honor tanta bajeza,

haga que con un engaño, sin que la conozca, pueda gozarle.

DiAnA:

Queda el peligro

de presumir que lo entienda.

¿No será mejor matarle?

[TEODORO:

¿Matarle?

DiAnA:

¿Qué es eso, tiemblas?] 
pero estas romanas pruebas son buenas entre gentiles.

DiAnA:

Bien dices; que no hay Lucrecias, ni Torcatos, ni Virginios en esta edad, y en aquélla hubo Faustinas, Teodoro, Mesalinas y Popeas.

Escríbeme algún papel que a este propósito sea, y queda con Dios [...]. pero estas romanas pruebas son buenas entre gentiles.

DIANA:

Bien dices; que no hay Lucrecias, ni Torc[u]atos, ni Virginios en esta edad, y en aquella hubo Faustinas, Teodoro, Mesalinas y Popeas. Escríbeme algún papel que a este propósito sea, y queda con Dios $[\ldots]$.
[0]

Escríbeme algún papel que a este propósito sea, y queda con Dios $[\ldots]$.

Por escasos que sean los cambios respecto al texto literario, introducir en el cotejo la versión para Estudio 1 permite afrontar un nuevo reto para la investigación: a pesar de ser un texto televisivo y de que pudiera caber la sensación de que estas adaptaciones se plegaban servilmente a la letra, ofrece más variantes que el largometraje y suprime estratégicamente varias tandas de versos. Además, si nos detenemos en las coincidencias de las dos versiones audiovisuales, ambas operan en los mismos versos en varias ocasiones, lo que nos da un precioso indicio de qué elementos (en la mayoría de los casos, de tipo gramatical) se consideran perjudiciales para la correcta intelección del (tel)espectador: «como la miro más cerca», cuyo inicio es sustituido por «que yo» y por «porque»; «pierde el jüicio de celos», al que se aplican las soluciones de cambiar «de» por «con los» y de alterar el orden de la frase; o el superlativo «necísima», que se torna «pues es muy necia» y «gran embustera es». Dentro de este ámbito, llama la atención la idéntica actuación frente a «esas finezas en mí», prefiriéndose rematar el verso con un «de mí», lo que revela que algo extraño se percibió en su construcción y sentido, pero tal vez convenga en este caso puntuar de otro modo el texto literario y entender lo siguiente: «aunque Marcela merezca esas finezas, en mí no ha habido tantas finezas». Y de índole léxica, y ya separando lo que proponen ambas versiones, resulta llamativo que la televisiva se vea en la necesidad de cambiar un «espantes» por «asustes», mientras que al largometraje lo que le chirría es el «esgrimidor» y prefiere «gladiador». Hemos de tener en cuenta que, como sucede en el propio teatro sobre las tablas, hay cambios que proceden de la dicción in situ y no de lo que se percibe en el texto escrito, y sabemos además, gracias al testimonio del adaptador que trabajó con Pilar Miró, que llegó un momento de elaboración, ya avanzado, en que se le prohibió llevar la obra de Lope consigo, y no fue hasta el montaje final cuando volvió a acudirse al texto (Pérez Sierra 1999: 100).

Establecer qué mecanismos operaron en versiones como estas dos puede ofrecer resultados sugestivos, y dobletes hay varios para comprobar convergencias y divergencias en los discursos cinematográfico y televisivo: en lo que atañe a 
nuestro objeto de estudio, además de los casos de El perro del hortelano y El alcalde de Zalamea (cuya versión para Estudio 1 corrió a cargo de Alberto González Vergel en 1968), contamos, por ejemplo, con La dama duende (Luis Saslavsky, 1945; Alfredo Castellón, 1979) y La dama boba (Manuel Iborra, 2006; Alberto González Vergel, 1969; Cayetano Luca de Tena, 1980), lo cual permite rescatar textos teatrales televisivos a los que poca atención se ha prestado (y no digamos ya respecto a lo verbal) y de los que se ha pensado que ofrecían rígidos esquemas en su traslación, cuando en su extenso espectro cronológico y bajo diversas denominaciones y formatos (Guarinos 1992 y 2010; Rodríguez Merchán 2014) han trazado, en realidad, virajes de gran interés.

\section{ReCAPITULACiÓN Y SUgESTIONES PARA EL ESTUdio}

Volviendo a nuestro punto de partida, y una vez realizadas estas calas, creo que atender al componente verbal permite, para empezar, que delimitemos el objeto de estudio. Cotejar los diálogos (y, cuando se produce, la voz over) de las películas con lo que figura en los textos literarios adaptados puede evitar, en consecuencia, la tendencia a tasar difusas «fidelidades», y propiciar, en cambio, que nos encomendemos a propósitos más concretos y útiles como el de valorar la idoneidad de los cambios en el entramado nuevo al que concurren esos elementos lingüísticos que proceden del texto de partida, y si conviven armónicamente con los creados ex profeso para el filme. Hemos, por tanto, de hablar en términos de pericia o incluso, si se me permite a mí ahora la paronomasia, de peripecia, ya que, por ejemplo, a Pilar Miró (Galán 1998: 16) o a Gutiérrez Aragón (2015: 136-137) trataron de disuadirlos en cuanto se conocieron sus «disparatados» proyectos de trasladar el verso de una obra teatral de Lope a una película y hacer un nuevo Quijote, respectivamente.

No se trata, como he procurado mostrar a través de muy variados ejemplos, de qué «cantidad» del texto literario se trasvasa al fílmico, dado que en la mayoría de los casos ha de obrarse mediante síntesis y, como hemos comprobado, muchas de ellas se han resuelto con gran habilidad. Tampoco es una cuestión de «cualidad» si tenemos en cuenta que cada película ha optado por procedimientos diferentes en lo que respecta al modo de hablar de sus personajes, porque ninguna razón hay para sostener que el criterio único ha de ser el rígido mantenimiento de lo que dicta el texto literario, como tampoco parece lógico que solo la modernización a ultranza sea la panacea para adaptar estas obras. Cada película, si sus artífices obran con inteligencia, buscará sus propias soluciones y recursos.

Tiene razón Heredero cuando explica que, en principio, una de las posibles dificultades para el adaptador de una obra como el Quijote es que «los diálogos literarios y prolijos se aclimatan con dificultad en la pantalla, puesto que los diálogos 
cinematográficos, con ser probablemente los más artificiosos que existen, llevan en su propia naturaleza la exigencia de aparentar ser completamente naturales» (2005: 22), pero él mismo había ofrecido antes la clave para que entendamos cómo pueden resolverse estas cuestiones de construcción del guion: «El personaje de Don Quijote se expresa en la novela que lo creó con un lenguaje exuberante y deliberadamente arcaico (que lo era así ya incluso para sus contemporáneos)» (2005: 22), en lo que han insistido especialistas en la lengua del Quijote como Rosenblat (1971: 26-32). Un personaje en particular se comporta de modo muy diferente al resto, y si su manera de expresarse resulta extraordinariamente llamativa, lo es ya para el resto de personajes de esa misma obra y el propio lector de la época, y no solo para el espectador de una película.

Así, respecto a este ámbito cualitativo, hemos de preguntarnos si las diversas decisiones (mantenimiento del verso o del lenguaje estilizado, modernización, variabilidad discursiva) resultan homogéneas, están justificadas y son consecuentes con lo que propone cada filme en particular, no si el componente verbal responde a la «realidad» del espectador. Esto lo ha entendido muy bien todo un gurú de los manuales para guionistas, Robert McKee, cuando aconseja que «la forma de hablar de los personajes no debe ser realista, pero sí parecernos creíble», porque «el diálogo suena auténtico cuando la acción verbal del personaje es coherente con sus motivaciones» (2018: 130-131) ${ }^{17}$.

Si don Quijote es un auténtico «arcaísmo andante» y eso afecta sobremanera a su modo de hablar, Lope parece decirnos que el amor (y su alambicada formulación lingüística) te desconcierta (El perro del hortelano) o incluso te torna elocuente (La dama boba), así que la estilización de los diálogos en las propuestas fílmicas, siempre que se opere de manera homogénea, no solo está justificada,

17 Procuré esbozar el fundamento teórico de este aspecto crucial en una propuesta de estudio del diálogo en los textos dramáticos llevados al cine (Malpartida Tirado 2006: 197-203), y creo que quienes mejor han apuntalado esta idea son Sánchez Noriega en los capítulos que dedica a «La palabra en la imagen» y «El diálogo», sobre todo cuando recuerda oportunamente que «el texto fílmico se construye también con el registro verbal» (2000: 39), y que «existe todo un cine de probada calidad estética y autonomía respecto a la literatura (Bergman, Woody Allen, Eric Rohmer) que se fundamenta en el diálogo, y este último director ha indicado: "Hago diálogos no literarios. La palabra forma parte del cine y de la vida. Describir las cosas con palabras es tan cinematográfico como mostrarlas con imágenes"» (2000: 124); y Wolf, quien señala en el capítulo «El diálogo: lo literario y lo cinematográfico» que «un primer aspecto que se discute es la recurrencia o abuso en la función poética del lenguaje, ya que pareciera que los diálogos cinematográficos exigen como certificado de probidad el respeto por el fluir vulgar de las palabras, sin proliferación de sinónimos, sin un uso culto de figuras retóricas, desprovistos del cuidado estilístico de la lengua que implicaría la palabra escrita», pero los «modos de decir no están aislados, sino imbricados en el contexto en que se insertan», y el problema (a propósito del monólogo, pero extensible también a los diálogos) «no está en el tipo de uso de la lengua sino en la justificación de esas elecciones» (2001: 56-60). 
sino que es plenamente consecuente con las historias que se están contando y con los personajes que las protagonizan. Incluso hay quien se lo toma a chanza, como el Lucas Trapaza de la serie televisiva El pícaro, y replica, ante una carta que parece algo alambicada, que «es la moda».

Caso muy distinto es el de las adaptaciones que terminan provocando efectos distorsionadores, no respecto al texto de partida, sino en relación con el nuevo entramado verbal que presentan. Así, por ejemplo, el Lazarillo de Ardavín y, en menor medida, el Alcalde de Zalamea de Camus, y por razones muy diferentes, como pudimos comprobar (la primera porque estaba muy condicionada por las fórmulas edulcoradas de las películas con «niño», y la segunda porque adaptaba dos textos en verso e ideaba goznes muy coloquiales para engarzarlos), no acertaron en la elaboración armónica de sus diálogos.

Sentadas estas premisas de tipo metodológico, creo que hay una primera pregunta muy básica que podríamos hacernos a la hora de afrontar un análisis más exhaustivo de estas adaptaciones: dado el propósito divulgativo (y, muy en particular, «pedagógico») que se ha otorgado a varias de estas películas, ¿las operaciones de tipo lingüístico que se han efectuado son semejantes a las de «Odres Nuevos», por citar un añejo ejemplo, o ediciones didácticas más modernas de los clásicos de nuestra literatura? Es más, teniendo en cuenta la propuesta de Wheeler (2018), ¿es lo audiovisual, en sí mismo, un «odre nuevo»? Me refiero, claro, a las adaptaciones de textos áureos que terminan formando parte de un proceso de «capitalización cultural» (España Arjona 2018). Sobre esta función vicariante del cine (que, desde luego, resulta exasperante, pero hemos de aceptarla y analizarla con cuidado) podría indagarse ahora que

el modelo de enseñanza humanístico está en crisis y es muy posible que esté a punto de caducar. Vivimos una época no solamente de la cultura sino de la enseñanza del espectáculo en la cual no es infrecuente que haya que luchar más por defender la presencia en las aulas del Fénix de los Ingenios que de la última pareja de Mario Vargas Llosa (Wheeler 2018: 278).

Pero, dando un paso más allá de esta cierta claudicación (como opina Wheeler) que acepta al medio audiovisual como un aliado (y no como un «invasor», según las concepciones más puristas y aún no superadas del todo) que puede despertar el interés por la obra literaria, es preferible, sin duda, reclamar la especificidad del cine y la televisión. Esto supone que hemos de estudiar qué mecanismos contribuyen a que una historia y unos personajes contenidos en un texto que se remonta a más de cuatro siglos puedan resultar atractivos para un espectador que no tiene por qué conocer la fuente más que de manera indirecta y al que tampoco se le está invitando, sin más, a leerla tras el visionado de ese «tráiler extenso» que para algunos representa la adaptación. Pensemos, por ejemplo, en las técnicas de 
conversión del discurso diegético en mimético, de manera que los diálogos cobran relieve, o en las necesarias operaciones (de síntesis, conversión o incluso ampliación) para imbricar adecuadamente palabra e imagen, que determinan el modo en que el componente verbal se muda al nuevo texto. La «habilidad» y el efecto de «dinamismo» son conceptos que han aflorado una y otra vez en los ejemplos que hemos recorrido, y no solo para lograr un objetivo difusor y mirando obsesivamente hacia el texto de partida, sino para construir un discurso fílmico que representa un fin en sí mismo. En El Buscón y en El caballero don Quijote, por ejemplo, no parece que se pretendiera «reconocimiento» alguno del texto literario por parte del espectador.

Por otra parte, y en busca de enriquecer el estudio con diversas soluciones, el cotejo no solo con películas o series televisivas, sino con otro tipo de adaptaciones y revisitaciones, podría resultar revelador y, en cierto modo, hasta desmitificador. Me refiero a lo que propone López Aranda (2006) con El Buscón teatral, o Lorca (Aguilera Sastre y Lizarraga Vizcarra 2001) y Mayorga con La dama boba (Molanes Rial y Candelas Colodrón 2011). Más complicado lo tenemos si queremos incorporar al estudio los guiones fílmicos, porque el de Blasco Ibáñez inspirado en el Quijote, que sí está editado (2015), discurre por predios que poco nos podrían aportar para este cometido (y, además, se gestó para el cine mudo). Disponemos, eso sí, de algunos fragmentos del que ideó Welles (2005), lo que nos llevaría a otro ámbito, el de la traductología, dado que fue escrito en inglés (y trasladado al español por Juan Cobos), y he eludido las películas en otras lenguas en las calas que he realizado para que el corpus resulte más homogéneo.

Por último, una precaución que debería tomarse si se abordara de manera más sistemática la incorporación del componente lingüístico en estos textos audiovisuales, es emplear ediciones críticas que nos permitan comprobar que las variaciones detectadas no proceden de que estamos cotejando con un texto diferente al que usaron los adaptadores. Creo que es una fórmula más práctica que la indagación sobre qué edición utilizaron en concreto, ya que ese es un dato que rara vez trasciende, y especular sobre la incidencia que el asesor filológico tuvo en esa decisión (¿Armando Cotarelo recomendó a Abad Ojuel el Quijote editado por Clemencín?) difícilmente va a resultar fructífera porque no iría más allá de una simple elucubración.

En definitiva, con estas sugestiones y prevenciones tal vez pueda evitarse la sensación de colapso exegético que inferíamos del estado de la cuestión. Si en unas simples calas atendiendo al ámbito verbal (y no a la etérea «fidelidad» que deba un texto a otro) puede apreciarse una variada gama de matices en las técnicas de adaptación, y detectarse, por ejemplo, que afloran los Sueños en una versión de El Buscón, creo que esta vía de estudio, emprendida más exhaustivamente y equilibrada con la atención al otro lenguaje, el de las imágenes, puede deparar gratas sorpresas. 


\section{BIBLIOGRAFÍA}

Acosta Romero, Ángel (1998). «Inquisición, censura y picaresca: “El Lazarillo” de Ardavín». En Natividad Cristina Carreras-Lario y Celia Crespo Gámez (coords.), Cien años de cine. La fábrica y los sueños. Sevilla: Universidad de Sevilla, pp. 15-23.

Aguilera Sastre, Juan e Isabel Lizarraga Vizcarra (2001). Federico García Lorca y el teatro clásico. La versión escénica de «La dama boba». Logroño: Universidad de La Rioja.

Alcaraz, Juan de (1998). "Antonio Abad Ojuel habla acerca de su adaptación de Don Quijote a la pantalla». En Emilio de la Rosa, Luis M. González y Pedro Medina (coords.), Cervantes en imágenes. Donde se cuenta cómo el cine y la televisión evocaron su vida y su obra. Alcalá de Henares: Festival de Cine de Alcalá de Henares / Ayuntamiento / Centro de Estudios Cervantinos, pp. 219-222.

Alonso Veloso, María José (2001). «El perro del hortelano, de Pilar Miró: una adaptación no tal fiel de la comedia de Lope de Vega». Signa, 10, pp. 375-393.

Anónimo (1994). Lazarillo de Tormes. Francisco Rico (ed.). Madrid: Cátedra.

Blasco IbáÑez, Vicente (2015). Don Quijote (Guion cinematográfico). Emilio José Sales (ed.). Madrid: Biblioteca Nueva.

Bonilla Cerezo, Rafael (2015). «Un Quijote de cine para niños grandes: Donkey Xote (José Pozo, 2007)». Anales cervantinos, XLVII, pp. 47-132.

Brasó, Enrique (2002). Conversaciones con Fernando Fernán Gómez. Madrid: Espasa Calpe.

Briones Manzano, Luisa (2012). «Los Quijotes de Gil, Gutiérrez, Welles y Gavaldón: nuevas aproximaciones teóricas». En Barbara Zecchi (ed.), Teoría y práctica de la adaptación filmica. Madrid: Editorial Complutense, pp. 85-96.

Buezo Canalejo, Catalina (2008). «De la novela al cine: El caballero Don Quijote, de Manuel Gutiérrez Aragón». En José Romera Castillo (ed.), Teatro, novela y cine en los inicios del siglo XXI. Madrid: Visor, pp. 389-402.

Calderón de la Barca, Pedro (1987). El alcalde de Zalamea. José María Díez Borque (ed.). Madrid: Castalia.

CARmona, Alba (2015). «Análisis de la recepción y canonización de las comedias del Siglo de Oro a partir de sus adaptaciones cinematográficas». En Carlos Mata Induráin y Ana Zúñiga Lacruz (coords.), «Venia docendi». Actas del IV Congreso Internacional Jóvenes Investigadores Siglo de Oro. Pamplona: Universidad de Navarra, pp. 7-21. Depósito Académico digital. Universidad de Navarra $<$ http://dadun.unav.edu/handle/10171/38565> [Consulta: 20/11/2017].

Carmona, Alba y Sònia Boadas (2016). “"O morir en la porfía o ser conde de Belflor”: la ambición de Teodoro en Lope de Vega y en Pilar Miró». Ogigia. Revista electrónica de estudios hispánicos, 20, pp. 5-23<http://www.ogigia.es/index.php/ ogigia/article/view/63> [Consulta: 20/11/2017]. 
Carmona, Alba, Purificació García Mascarell y Gaston Gilabert (2018). «Presentación: La escena y la pantalla. Lope hoy». Anuario Lope de Vega. Texto, literatura, cultura, XXIV, pp. 1-9.

CArpentier, Alejo (1990). «Un absurdo intento». Letra y solfa. Cine. I. Crónicas sobre cine. 1951-1959. Barcelona: Mondadori, pp. 192-193.

Carrera, Mauricio (2001). «El negro Zaide: la crítica del racismo en el Lazarillo de Tormes». Revista de la Universidad de México, 600-601, pp. 13-19.

Cervantes, Miguel de (1998). Don Quijote de la Mancha. F. Rico (dir.). Barcelona: Crítica / Instituto Cervantes. Centro Virtual Cervantes <https:/cvc.cervantes.es/ literatura/clasicos/quijote/default.htm $>$ [Consulta: 11/02/2018].

Cortés IBÁÑEz, Emilia (2000). «Un clásico en el cine: El perro del hortelano». En Florencio Sevilla y Carlos Alvar (eds.), Actas del XIII Congreso de la Asociación Internacional de Hispanistas. IV. Madrid: Castalia, pp. 303-308. Centro Virtual Cervantes $<\mathrm{https}: / /$ cvc.cervantes.es/literatura/aih/pdf/13/aih_13_4_035.pdf $>$ [Consulta: 20/11/2017].

Criado de VAL, Manuel (1979). «En Don Quijote de la Mancha» [Entrevista]. Tele Radio, 1114, pp. 31-32<http://www.quijote.tv/cdval.htm> [Consulta: 23/01/2018].

CRUZ-CÁMARA, Nuria y Gregory KAPLAN (2002). «Una revisitación franquista del Lazarillo de Tormes». En Norberto Mínguez (coord.), Literatura española y cine. Madrid: Editorial Complutense, pp. 27-42.

Díez MÉnguez, Isabel (2002). «Adaptación cinematográfica de El perro del hortelano, por Pilar Miró». En José Romera Castillo, Francisco Gutiérrez Carbajo y Dolores Romero López (eds.), Del teatro al cine y la televisión en la segunda mitad del siglo XX. Madrid: Visor, pp. 301-308.

Escalonilla López, Rosa Ana (2002). «La vigencia dramática de la comedia nueva en la película El perro del hortelano, de Pilar Miró». En José Romera Castillo, Francisco Gutiérrez Carbajo y Dolores Romero López (eds.), Del teatro al cine y la televisión en la segunda mitad del siglo XX. Madrid: Visor, pp. 308-319.

España ArJona, Manuel (2017). La recepción de la narrativa picaresca en la serie televisiva El Pícaro (Fernando Fernán-Gómez, 1974). Santiago de Compostela: Andavira.

España ArJona, Manuel (2018). «Lope de Vega como capital cultural. El caso de El perro del hortelano de Pilar Miró». En Rafael Malpartida Tirado (coord.), Recepción $y$ canon de la literatura española en el cine. Madrid: Síntesis, pp. 139-156.

España Arjona, Manuel (2018). «Tres lazarillos fílmicos y otros casos». Quimera, 410 , pp. 18-21.

EsPaña, Rafael de (2003). «El cine es sueño. El difícil paso a la pantalla de los autores del Siglo de Oro». Studi Ispanici, 6, pp. 35-50.

España, Rafael de (2007). De la Mancha a la pantalla. Aventuras cinematográficas del Ingenioso Hidalgo. Barcelona: Universitat de Barcelona.

Espinel, Vicente (1972). Vida del escudero Marcos de Obregón. I. María Soledad Carrasco Urgoiti (ed.). Madrid: Castalia. 
Fernández, Esther y Cristina Martínez-CARAzo (2006). «Mirar y desear: la construcción del personaje femenino en El perro del hortelano de Lope de Vega y de Pilar Miró». Bulletin of Spanish Studies, LXXXIII/3, pp. 315-328.

Fra Molinero, Baltasar (1993). «El negro Zaide: marginación social y textual en el Lazarillo». Hispania, 76, pp. 20-29.

Galán, Diego (1998). «Entrevista [a Pilar Miró]». Nosferatu, 28, pp. 6-16.

Gómez Mesa, Luis (1978). La literatura española en el cine nacional (Documentación y crítica). Madrid: Filmoteca Nacional de España.

GonzÁlez Egido, Luciano (1960). «Lazarillo de Tormes, 1959». Cinema universitario, 13, pp. 24-31. Centro Virtual Cervantes <http://www.cervantesvirtual.com/obra-visor/ cinema-universitario--17/html/0256f140-82b2-11df-acc7-002185ce6064.html> [Consulta: 19/12/2017].

Guarinos, Virginia (1992). Teatro y televisión. Sevilla: Centro Andaluz de Teatro/Alfar. GuARINOs, Virginia (2010). «El teatro en TVE durante la Transición (1975-1982). Un panorama con freno y marcha atrás». En Antonio Ansón et alii (eds.), Televisión y Literatura en la España de la Transición (1973-1982). Zaragoza: Institución Fernando el Católico / Diputación, pp. 97-118.

GÜNTERT, Georges (2006). «El carácter prefigurativo de los capítulos iniciales de $E l$ Buscón y su tematización del código de lectura». La Perinola, 10, pp. 149-158.

Gutiérrez Aragón, Manuel (2015). A los actores. Barcelona: Anagrama.

Heredero, Carlos F. (2005). «Don Quijote en la pantalla. Diálogos entre la literatura y el cine». En Don Quijote y el cine. Madrid: Filmoteca Nacional, pp. 21-97.

HERnÁNDEZ RuIz, Javier (1998). «Una aventura cervantina de la ficción/metaficción: desafíos narrativos y juegos autoconscientes en el cine». En Emilio de la Rosa, Luis M. González y Pedro Medina (coords.), Cervantes en imágenes. Donde se cuenta cómo el cine y la televisión evocaron su vida y su obra. Alcalá de Henares: Festival de Cine de Alcalá de Henares / Ayuntamiento / Centro de Estudios Cervantinos, pp. 139-156.

HeRnÁNDEZ, Javier (2005). «Manuel Gutiérrez Aragón o los Quijotes de la democracia». Nosferatu, 50, pp. 18-22.

Herranz, Ferran (2005). El Quijote y el cine. Madrid: Cátedra.

Iborra, Manuel (2011). «Lope y el cine». En Fernando Doménech y Julio Vélez-Sainz (eds.), Arte nuevo de hacer teatro en nuestro tiempo. Madrid: Ediciones del Orto, pp. 135-140.

JAIME, Antoine (2000). Literatura y cine en España (1975-1995). Madrid: Cátedra.

KERCHER, Dona M. (2002). «Looking for Don Quijote's Own Shadow: An Interview with Manuel Gutiérrez Aragón about His Film El caballero Don Quijote (2002)». Arizona Journal of Hispanic Cultural Studies, 6, pp. 129-140.

LARA, Fernando (1998). «El Quijote. Variaciones sobre un mito». En Emilio de la Rosa, Luis M. González y Pedro Medina (coords.), Cervantes en imágenes. Donde 
se cuenta cómo el cine y la televisión evocaron su vida y su obra. Alcalá de Henares: Festival de Cine de Alcalá de Henares / Ayuntamiento / Centro de Estudios Cervantinos, pp. 79-86.

LAZARo CARreter, Fernando (1979). «Imitación compuesta y diseño retórico en la oda a Juan de Grial». Anuario de estudios filológicos, 2, pp. 89-119.

López Aranda, Ricardo (2006). El Buscón. Centro Virtual Cervantes <http://www. cervantesvirtual.com/obra/el-buscon--0/> [Consulta: 26/01/2018].

LóPez López, Yolanda (2017). El Siglo de Oro en el cine y la ficción televisiva. Madrid: ACCI.

Malpartida Tirado, Rafael (2006). «Del diálogo dramático al diálogo fílmico: una propuesta de estudio». Analecta Malacitana, XXIX/1, pp. 197-214.

Malpartida TiRAdo, Rafael (2018). «La recepción y el canon de la literatura y el cine: sugestiones y replanteamientos». En Rafael Malpartida Tirado (coord.), Recepción y canon de la literatura española en el cine. Madrid: Síntesis, pp. 17-53.

Malpartida Tirado, Rafael (2018). «Novela corta y cine: el caso de El curioso impertinente». eHumanista. Journal of Iberian Studies, 38, pp. 657-672.

Mañas Martínez, María del Mar (2006). «Don Quijote de la Mancha, de Rafael Gil: una adaptación literaria del cine español en las conmemoraciones cervantinas de 1947». Anales cervantinos, XXXVIII, pp. 67-93.

Matamoro, Blas (2003). «En ningún lugar de la mancha». Studi Ispanici, 6, pp. 51-59.

Merino, José María (2003). «Manuel Gutiérrez Aragón: El caballero don Quijote». Revista de Libros, $73<\mathrm{https}$ //www.revistadelibros.com/articulos/manuelgutierrezaragon-el-caballero-don-quijote> [Consulta: 24/10/2017].

Miguel Borrás, Mercedes y Alberto ÚBedA-Portugués (2010). Luciano Berriatúa, gran aventurero y explorador de cine. Madrid: Plataforma de Nuevos Realizadores.

Molanes Rial, Mónica y Manuel Ángel Candelas Colodrón (2011). «Las adaptaciones lopescas de Juan Mayorga: La dama boba en el siglo XXI». Anuario Lope de Vega. Texto, literatura, cultura, XVII, pp. 66-84.

Noble Wood, Oliver (2015). «A Silly Little Thing Called Love: Foolishness, Farce, and Fancy in Manuel Iborra's La dama boba (2006)». En Aaron M. Kahn (ed.), Connecting Past and Present. Exploring the Influence of the Spanish Golden Age in the Twentieth and Twenty-First Centuries. Newcastle: Cambridge Scholars Publishing, pp. 187-209.

Pardo García, Pedro Javier (2011). «Cine, literatura y mito: Don Quijote en el cine, más allá de la adaptación». Arbor, 748, pp. 237-246.

Pardo García, Pedro Javier (2013). «Don Quijote cabalga de nuevo. Reescrituras del mito quijotesco». En José Antonio Pérez Bowie (ed.), La noche se mueve. La adaptación en el cine del tardofranquismo. Madrid: Catarata, pp. 181-227.

PAYÁN, Miguel Juan (2005), «Don Quijote en televisión». En Miguel Juan Payán (coord.), El Quijote en el cine. Madrid: Jaguar, pp. 135-154. 
Pérez Bowie, José Antonio (2001). «Teatro en verso y cine: una relación conflictiva». Anales de la literatura española contemporánea, 26/1, pp. 317-335.

Pérez Bowie, José Antonio (2004). Cine, literatura y poder. La adaptación cinematográfica durante el primer franquismo (1939-1950). Salamanca: Librería Cervantes.

Pérez Bowie, José Antonio y Fernando González García (2010). El mercado vigilado. La adaptación en el cine español de los 50. Murcia: Tres Fronteras Ediciones.

Pérez Sierra, Rafael (1999). «Historia de una experiencia: El perro del hortelano». En Agustín de la Granja, Heraclia Castellón Alcalá y Antonio Serrano Agulló (coords.), En torno al teatro del Siglo de Oro. Almería: Instituto de Estudios Almerienses, pp. 93-102.

Pérez Sierra, Rafael (1999). "Versión cinematográfica de El perro del hortelano». En Felipe B. Pedraza Jiménez y Rafael González Cañal (eds.), Lope de Vega: comedia urbana y comedia palatina. Cuenca / Ciudad Real: Universidad de Castilla-La Mancha / Festival de Almagro, pp. 107-114.

Praga Terente, Jorge (2016). «Del difícil ascenso de don Quijote a la pantalla de cine, o el triunfo de la maldición cervantina». En VV.AA., Colecciones cervantinas. Madrid: MECD, pp. 163-171.

Quesada, Luis (1986). La novela española y el cine. Madrid: JC.

Quevedo, Francisco de (1993). Sueños y discursos. James O. Crosby (ed.). Madrid: Castalia.

Quevedo, Francisco de (2017). El Buscón. Domingo Ynduráin (ed.). Madrid: Cátedra.

Rodríguez Merchán, Eduardo (2014). "Antecedentes, orígenes y evolución de un programa mítico: Estudio 1 de TVE». Estudios sobre el Mensaje Periodístico, 20, pp. 267-279.

RosA, Emilio de la (1998). «Don Quijote se anima». En Emilio de la Rosa, Luis M. González y Pedro Medina (coords.), Cervantes en imágenes. Donde se cuenta cómo el cine y la televisión evocaron su vida y su obra. Alcalá de Henares: Festival de Cine de Alcalá de Henares / Ayuntamiento / Centro de Estudios Cervantinos, pp. 101-120.

Rosenblat, Ángel (1971). La lengua del «Quijote». Madrid: Gredos.

SÁnchez Noriega, José Luis (1998). Mario Camus. Madrid: Cátedra.

SÁnchez Noriega, José Luis (2000). De la literatura al cine. Teoría y análisis de la adaptación. Barcelona: Paidós.

SÁnchez Noriega, José Luis (2005). «Humor y utopía en los Quijotes de Manuel Gutiérrez Aragón». BBMP, LXXXI, pp. 607-635.

SÁnchez Noriega, José Luis (2011). «Teatro y cine. El drama del verso en la pantalla». En Fernando Doménech y Julio Vélez-Sainz (eds.), Arte nuevo de hacer teatro en nuestro tiempo. Madrid: Ediciones del Orto, pp. 131-134.

SAntamarina, Antonio (2002). «Del optimismo renacentista a la crisis barroca. Las adaptaciones cinematográficas del Siglo de Oro». Cuadernos de la Academia (La imprenta dinámica. Literatura española en el cine español), 11, pp. 167-188. 
Shu-YING ChANG, Luisa (2002). «Lazarillo de Tormes: variantes de la técnica narrativa de la novela al cine». En Francisco Domínguez Matito y María Luisa Lobato López (coords.), Memoria de la palabra. Actas del VI Congreso de la Asociación Internacional Siglo de Oro. I. Madrid: Iberoamericana, pp. 511-523.

STAM, Robert (2014). Teoría y práctica de la adaptación. México: UNAM.

Tejada Medina, María del Rosario (1997). «Aproximación al lenguaje cinematográfico de Don Quijote de la Mancha. Tranco III». En Carlos J. Gómez Blanco (coord.), Literatura y cine: perspectivas semióticas. La Coruña: Universidad, pp. 127-143.

THIEM, Annegret (2009). «Formas de la teatralidad en El perro del hortelano (1995) de Pilar Miró». En Verena Berger y Mercè Saumell (coords.), Escenarios compartidos. Cine y teatro en España en el umbral del siglo XXI. Viena: Lit Verlag, pp. 49-59.

Torres, Augusto M. (2004). Directores españoles malditos. Madrid: Huerga y Fierro.

TreCCA, Simone (2011). «La adaptación fílmica de La dama boba». En Antonio Azaustre Galiana y Santiago Fernández Mosquera (coords.), Compostella aurea. Actas del VIII Congreso de la Asociación Internacional del Siglo de Oro. III. Santiago de Compostela: Universidad, pp. 467-475.

TrecCA, Simone (2015). «Falsos amigos en la adaptación fílmica del texto dramático: el caso del diálogo». En José Antonio Pérez Bowie y Pedro Javier Pardo García (eds.), Transescrituras audiovisuales. Madrid: Sial Pigmalión, pp. 157-169.

Usero Cañestro, Jesús (2005). «El caballero Don Quijote, 2002». En Miguel Juan Payán (coord.), El Quijote en el cine. Madrid: Jaguar, pp. 111-119.

Utrera, Rafael (2001). «Don Quijote, Don Juan y La Celestina vistos por el cine español». En Christoph Strosetzki (coord.), Actas del V Congreso de la Asociación Internacional Siglo de Oro. Madrid: Iberoamericana, pp. 12861295. Centro Virtual Cervantes <https://cvc.cervantes.es/literatura/aiso/pdf/05/ aiso_5_126.pdf $>$ [Consulta: 14/12/2017].

Utrera, Rafael (2007). Literatura y cine. Adaptaciones. I. Del teatro al cine. Sevilla: Padilla Libros.

Vega, Lope de (1970). El perro del hortelano. El castigo sin venganza. A. David Kossoff (ed.). Madrid: Castalia.

VEGA, Lope de (1998). El alcalde de Zalamea [atrib.]. En Juan M. Escudero Baztán, El alcalde de Zalamea. Edición crítica de las dos versiones. Madrid / Frankfurt a. M.: Iberoamericana / Vervuert, pp. 379-498.

VILCHES, Ángel (1998): «El Quijote no puede verse de una u otra manera, sino sólo como lo escribió Cervantes». En Emilio de la Rosa, Luis M. González y Pedro Medina (coords.), Cervantes en imágenes. Donde se cuenta cómo el cine y la televisión evocaron su vida y su obra. Alcalá de Henares: Festival de Cine de Alcalá de Henares / Ayuntamiento / Centro de Estudios Cervantinos, pp. 215-217.

Welles, Orson (2005). Don Quijote. Páginas del guión cinematográfico. Madrid: Publicaciones de la Asociación de Directores de Escena de España. 
WheELER, Duncan (2018). «Las adaptaciones cinematográficas como (posible) herramienta pedagógica». Anuario Lope de Vega. Texto, literatura, cultura, XXIV, pp. 260-287.

Wolf, Sergio (2001). Cine/Literatura. Ritos de pasaje. Buenos Aires: Paidós.

Recibido: 27/09/2018

Aceptado: 20/10/2018 
El COMPONENTE VERBAL EN LAS ADAPTACIONES DE LA LITERATURA ÁUREA ESPAÑOLA AL CINE Y LA TELEVISIÓN: UNA PROPUESTA DE ESTUDIO

RESUMEN: En este trabajo se propone atender a un aspecto muy poco explorado en los estudios sobre las adaptaciones de la literatura áurea española al cine y la televisión: el componente verbal. A través de unas calas significativas por la narrativa (El Buscón, el Lazarillo de Tormes o el Quijote) y el teatro (El alcalde de Zalamea y El perro del hortelano) llevados al medio audiovisual, se llama la atención sobre los problemas metodológicos que representa la fidelity criticism y se invita, en cambio, a analizar la coherencia y la armónica integración de los elementos lingüísticos procedentes de los textos literarios en las películas y series televisivas.

Palabras Clave: adaptación cinematográfica, fidelity criticism, lengua del Siglo de Oro, diálogos.

THE VERBAL COMPONENT IN THE ADAPTATIONS OF THE GOLDEN AGE SPANISH LITERATURE TO CINEMA AND TELEVISION: A STUDY PROPOSAL

ABSTRACT: This paper proposes an aspect that has been little explored in the studies on the adaptations of the Golden Age Spanish Literature to cinema and television: the verbal component. Through some significant examples of the narrative (El Buscon, Lazarillo de Tormes or Quijote) and the theater (El Alcalde de Zalamea and El perro del hortelano) adapted to the audiovisual medium, attention is drawn to the methodological problems represented by the fidelity criticism, and advocates, as an alternative, an analysis of the coherence and harmonious integration of linguistic elements coming from literary texts in films and television series.

KEYWORDS: film adaptation, fidelity criticism, language of the Golden Age, dialogues. 


\section{Edad de Oro. Revista de Filología Hispánica}

ISSN: 0212-0429 - ISSNe: 2605-3314 <https://revistas.uam.es/edadoro/index>

Edad de Oro es uno de los máximos referentes en el área de investigación en Filología Hispánica, especialmente de los siglos XVI y XVII. Goza de un amplio reconocimiento en el ámbito académico internacional. Desde 1982 publica ininterrumpidamente, con una periodicidad anual, colaboraciones científicas de los principales especialistas de diversos centros nacionales y extranjeros. Con un público compuesto esencialmente por investigadores y expertos de todo el mundo, se dirige a cualquier persona interesada en las nuevas corrientes de los estudios humanísticos de su campo.

Dirección:

María Jesús Zamora Calvo

(Univ. Autónoma de Madrid)

Subdirección:

José Antonio Llera Ruiz

(Univ. Autónoma de Madrid)

Secretaría:

Raquel Arias Careaga

(Univ. Autónoma de Madrid)

Consejo de redacción:

Cecilia López-Ridaura

(ENES. Morelia / Univ. Nacional

Autónoma de México)

José Luis Ocasar Ariza

(Univ. Autónoma de Madrid)

Rocío Pérez Gironda

(Univ. Autónoma de Madrid)

Carolina Fernández Cordero

(Iberoamericana-Vervuert)

Admisión de originales:

María Jesús Zamora Calvo

Edad de Oro

Universidad Autónoma de Madrid

Facultad de Filosofía y Letras

Departamento de Filología Española

Campus Cantoblanco

28049 Madrid (España)

Tfno. (+34) 914976886

Correo-e: mariajesus.zamora@uam.es

Distribución, suscripción y venta:

Servicio de Publicaciones de la UAM

Universidad Autónoma de Madrid

28049 Madrid (España)
Intercambio de publicaciones:

Biblioteca de Humanidades

Universidad Autónoma de Madrid

28049 Madrid (España)

Comité científico:

Carlos Alvar (Université de Gèneve)

Ignacio Arellano (Univ. de Navarra)

Alberto Blecua

(Univ. Autónoma de Barcelona)

Jean Canavaggio

(Université Paris Nanterre)

Aurora Egido (Univ. de Zaragoza)

Víctor García de la Concha (RAE)

Luciano García Lorenzo (CSIC)

Joaquín González Cuenca

(Univ. de Castilla la Mancha)

Agustín de la Granja López

(Univ. de Granada)

Begoña López Bueno (Univ. de Sevilla)

Michel Moner

(Universitè Toulouse - Jean Jaurès)

Joan Oleza (Univ. de Valencia)

Alfonso Rey

(Univ. de Santiago de Compostela)

Lina Rodríguez Cacho

(Univ. de Salamanca)

Leonardo Romero Tobar

(Univ. de Zaragoza)

Aldo Ruffinatto

(Università degli Studi di Torino)

Lía Schwartz

(City University of New York)

Han colaborado en este volumen:

Departamento de Filología Española

(UAM)

Facultad de Filosofía y Letras (UAM)

Edad de Oro se recoge en las siguientes bases de datos y directorios: DICE; HLAS; MLA International Bibliography; PIO; ISOC-CSIC; DIALNET; SUMARIS CBUC; ULRICH'S.

Se encuentra evaluada en: SCOPUS: Q2; SCImago: SJR 2017 0.11, H Index 4; ERIH Plus: category A; CIRC: categoría C; RESH: 0.162; MIAR: ICDS 2017 10.0; CARHUS Plus+: C; LATINDEX. 


\section{EDAD DE ORO}

Revista de Filología Hispánica XXXVII

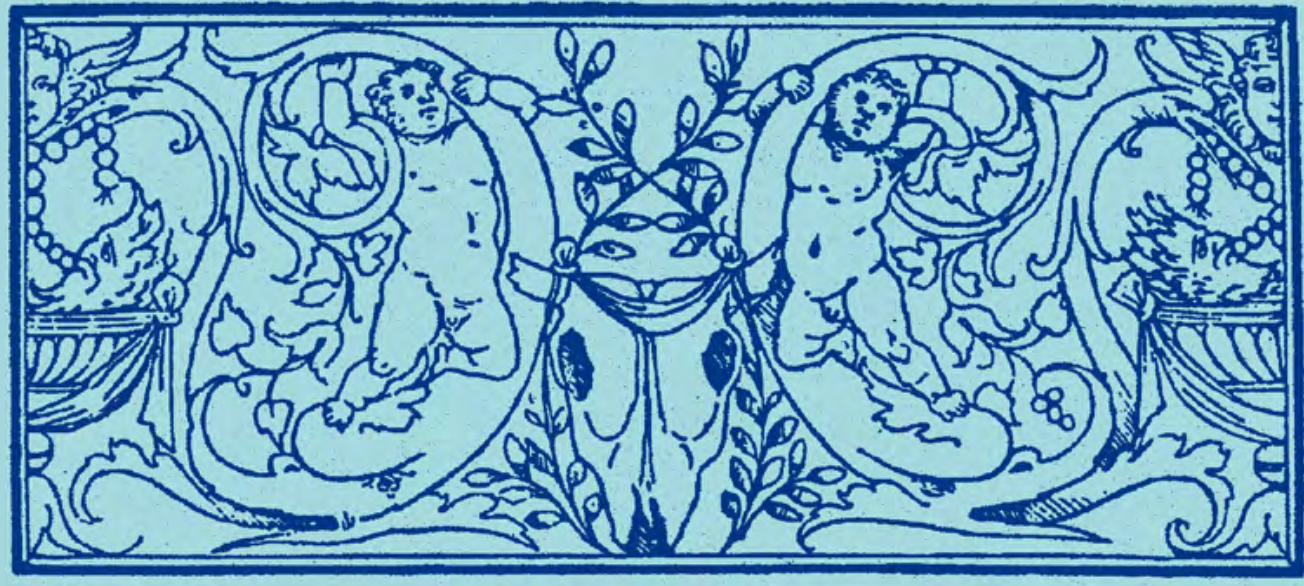

\section{DEPARTAMENTO DE FILOLOGÍA ESPAÑOLA}

EDICIONES DE LA UNIVERSIDAD AUTÓNOMA DE MADRID 